\title{
South Pacific Subtropical High from the late Holocene to the end of the 21st century: insights from climate proxies and general circulation models
}

\author{
Valentina Flores-Aqueveque ${ }^{1,3}$, Maisa Rojas ${ }^{2,3,4}$, Catalina Aguirre ${ }^{4,5,6}$, Paola A. Arias ${ }^{7}$, and Charles González ${ }^{1}$ \\ ${ }^{1}$ Departamento de Geología, Facultad de Ciencias Físicas y Matemáticas, Universidad de Chile, \\ Plaza Ercilla 803, Santiago, Chile \\ ${ }^{2}$ Departamento de Geofísica, Facultad de Ciencias Físicas y Matemáticas, Universidad de Chile, \\ Blanco Encalada 2002, Santiago, Chile \\ ${ }^{3}$ Millennium Nuclei for Paleoclimate, Universidad de Chile, Las Palmeras 3425, Nuñoa, Santiago, Chile \\ ${ }^{4}$ Centro de Ciencia del Clima y la Resiliencia (CR2, FONDAP 15110009), Chile \\ ${ }^{5}$ Escuela de Ingeniería Civil Oceánica, Facultad de Ingeniería, Universidad de Valparaíso, Chile \\ ${ }^{6}$ Centro de Observación Marino para estudios de Riesgos del Ambiente Costero (COSTA-R), Valparaíso, Chile \\ ${ }^{7}$ Grupo de Ingeniería y Gestión Ambiental (GIGA), Escuela Ambiental, Facultad de Ingeniería, \\ Universidad de Antioquia, Medellín, Colombia
}

Correspondence: Valentina Flores-Aqueveque (vfloresa@uchile.cl)

Received: 5 June 2019 - Discussion started: 3 July 2019

Revised: 21 November 2019 - Accepted: 27 November 2019 - Published: 10 January 2020

\begin{abstract}
The South Pacific Subtropical High (SPSH) is a predominant feature of the South American climate. The variability of this high-pressure center induces changes in the intensity of coastal alongshore winds and precipitation, among others, over southwestern South America. In recent decades, strengthening and expansion of the SPSH have been observed and attributed to the current global warming. These changes have led to an intensification of the southerly winds along the coast of northern to central Chile and a decrease in precipitation from central to southern Chile. Motivated by improving our understanding about the regional impacts of climate change in this part of the Southern Hemisphere, we analyzed SPSH changes during the two most extreme climate events of the last millennium, the Little Ice Age (LIA) and the Current Warm Period (CWP: 1970-2000), based on paleoclimate records and CMIP5/PMIP3 model simulations. In order to assess the level of agreement of general circulation models, we also compare them with ERA-Interim reanalysis data for the 1979-2009 period as a complementary analysis. Finally, with the aim of evaluating future SPSH behavior, we include 21st century projections under a Representative Concentration Pathway (RCP8.5) scenario in our analyses. Our results indicate that during the relative warm (cold)
\end{abstract}

period, the SPSH expands (contracts). Together with this change, alongshore winds intensify (weaken) south (north) of $\sim 35^{\circ} \mathrm{S}$; also, southern westerly winds become stronger (weaker) and shift southward (northward). Model results generally underestimate reanalysis data. These changes are in good agreement with paleoclimate records, which suggest that these variations could be related to tropical climate dynamics but also to extratropical phenomena. However, although models adequately represent most of the South American climate changes, they fail to represent the Intertropical Convergence Zone-Hadley cell system dynamics, emphasizing the importance of improving tropical system dynamics in simulations for a better understanding of its effects on South America. Climate model projections indicate that changes recently observed will continue during the next decades, highlighting the need to establish effective mitigation and adaptation strategies against their environmental and socioeconomic impacts. 


\section{Introduction}

Climate conditions in South America (SA) are the result of the complex interactions among predominant atmospheric circulation patterns, orographic features, latitudinal differential radiation, and heat and water balances. One of the main features dominating climate in this region, in particular its western boundary, is the South Pacific Subtropical High (SPSH), a quasi-permanent center of high atmospheric pressure developed over the southeastern Pacific Ocean. The present-day behavior of the SPSH is relatively well known. The SPSH varies (intensity and position) at different timescales, from seasonal to interannual, depending on the interplay between forcing from higher and lower latitudes (Grotjahn, 2004) and the superposition of largescale phenomena at interannual timescales, such as the El Niño-Southern Oscillation (ENSO; Cane, 1998), as well as the Pacific Decadal Oscillation (PDO; Mantua et al., 1997) at inter-decadal timescales (Ancapichún and Garcés-Vargas, 2015). SPSH changes, in turn, influence other elements of the ocean-atmosphere dynamics of SA, such as the meridional winds and the related upwelling along coastal central Peru to south-central Chile (e.g., Pizarro et al., 1994; Falvey and Garreaud, 2009; Rahn and Garreaud, 2013), as well as precipitation at the western side of the Andes (e.g., Barrett and Hameed, 2017).

However, little is known about its past behavior. During recent decades, an intensification of coastal southerly winds and a decrease in precipitation have been observed in southwestern SA. These changes have been related to an intensified and southward-shifted SPSH as a response to the current global warming scenario (Falvey and Garreaud, 2009; Rahn and Garreaud, 2013; Ancapichún and Garcés-Vargas, 2015; Schneider et al., 2017; Boisier et al., 2018; Aguirre et al., 2018). Model projections indicate that this trend will continue during the 21st century for southerly wind intensity (e.g., Garreaud and Falvey, 2009; Belmadani et al., 2014; Aguirre et al., 2018), as well as for precipitation (e.g., Nuñez et al., 2008; Kitoh et al., 2011; Cabré et al., 2016).

Given the fundamental impact of the SPSH on the alongshore winds, and therefore on wind-driven upwelling along the southeastern Pacific (Croquette et al., 2007; Aguirre et al., 2018) and precipitation (Barrett and Hameed, 2017), the study of SPSH past variations is essential for understanding its future behavior and key for diagnosing the impacts of climate change on the ecohydrologic dynamics and socioeconomic activities in this region, such as fisheries.

In this work, we analyze the SPSH past variations and their influence on the climate of western SA during the last millennium - a period in which natural and anthropogenic forcing can be evaluated - from two lines of evidence: paleoclimate proxies and general circulation models (GCMs). In particular, we focus on two extreme climate periods, the cold Little Ice Age (LIA) and the Current Warm Period (CWP), in order to contrast the SPSH behavior under different global and/or regional temperature conditions. Model data for the CWP period are compared with European Centre for Medium-Range Weather Forecasts (ECMWF) ERA-Interim Reanalysis data to evaluate the degree of agreement between GCMs and recent "observations". In addition, with the aim of understanding future SPSH conditions and their consequences, we also include 21 st century projections under an RCP8.5 scenario in our analyses.

The structure of this paper is organized as follows. First, a climate background of present-day and past changes in the SA climate is presented. Section 2 details the model and reanalysis data analyzed, as well as the periods and paleoclimate records considered. Section 3 presents the results obtained from global model simulations and their comparison with reanalysis data and with the information interpreted from paleoclimate records, as well as a discussion of this evidence. Finally, Sect. 4 summarizes the main findings and conclusions from this work.

\subsection{Present-day climate of southwestern South America and future projections}

In the Southern Hemisphere ( $\mathrm{SH})$, the subsiding branch of the Hadley cell (HC) determines the presence of a quasipermanent belt of high surface pressure around $30^{\circ} \mathrm{S}$ (e.g., Held and Hou, 1980), whose development over the Pacific Ocean is known as the SPSH. The SPSH extends over much of the Pacific Ocean off the Chilean coast, with a center between $25-30^{\circ} \mathrm{S}$ and $90-105^{\circ} \mathrm{W}$ (Pizarro et al., 1994) and an area of influence extending poleward of $45^{\circ} \mathrm{S}$ during austral summer (Fig. 1a), when it strengthens (Fuenzalida, 1971). At the northern edge of the SPSH, the air masses flow westward, producing the belt of the trade winds (tropical easterlies). South of the SPSH, a westerly wind belt, known as the southern westerly winds (SWWs), is developed in the midlatitudes, peaking around $50^{\circ} \mathrm{S}$ (Varma et al., 2012) (Fig. 1a). These prevailing winds, which are responsible for the very high regional precipitation on the windward side of the southern Andes (1000-7000 $\mathrm{mm} \mathrm{yr}^{-1}$; Garreaud et al., 2013), are characterized by a remarkable seasonality driven mainly by changes in sea surface temperature (SST) and atmospheric temperature gradients (Sime et al., 2013). Seasonally, the SPSH is strongest in intensity and has a more poleward position during austral summer, and it has a more equatorward position and less intensity during austral winter (Fig. 1a), allowing midlatitude frontal systems to reach further north and bringing winter rains to central Chile (e.g., Quintana and Aceituno, 2012).

The present-day climatic influence of the SPSH over SA is modulated by large-scale climatic phenomena at interannual to decadal timescales. ENSO (Cane, 1998) dominates global climate variations for the Pacific and the global tropics (Rasmussen and Wallace, 1983) on interannual timescales, ranging quasi-regularly from 3 to 6 years and between 2 and 7 years, according to Dettinger et al. (2000) and Cane (2005), 

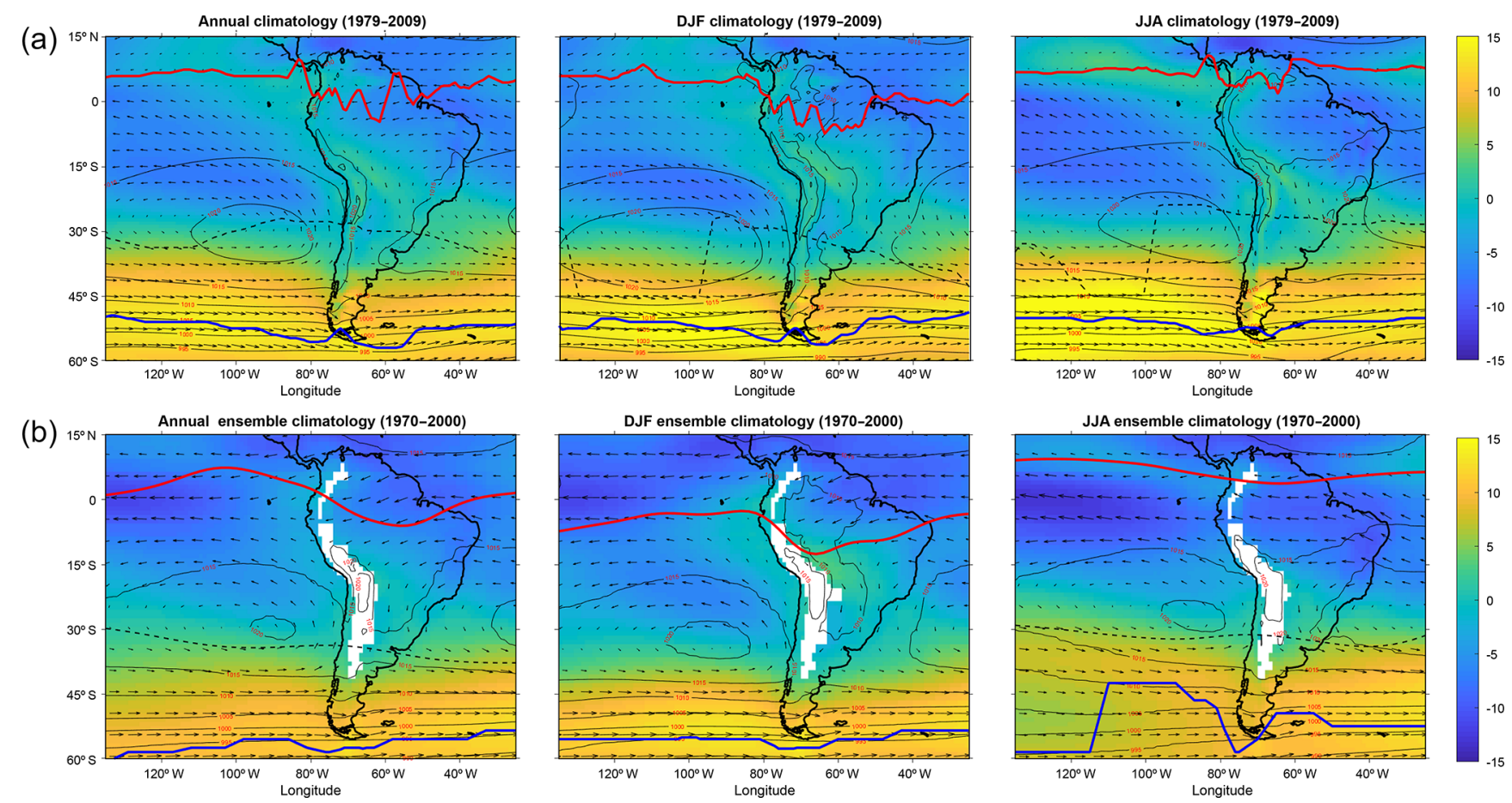

Figure 1. Present-day climate of southwestern South America. (a) ERA-Interim (1970-2009) and (b) ensemble model (1970-2000) climatology. Magnitude (color) and direction (vectors) denote the wind stress in the eastern Pacific Ocean for the annual mean, DJF, and JJA. The red line denotes the ITCZ position, the contour line $(1020 \mathrm{hPa})$ indicates the SPSH extension, the black dashed line corresponds to the STJ position, and the blue line denotes the position of the SWWs.

respectively. In southwestern SA, this phenomenon is associated with a higher probability of heavy rainfall in central Chile during the winter season, catastrophic flooding in coastal Peru, and drought in the Altiplano of Peru and Bolivia (Cane, 2005). At decadal timescales (20 to 30 years; Mantua and Hare, 2002), the influence of the PDO (Mantua et al., 1997; Zhang et al., 1997) plays a major role in the South American climate. This climate pattern is described as El Niño-like, mainly because its warm (cold) phases are very similar to those of El Niño (La Niña) events, although of smaller amplitude (Garreaud and Battisti, 1999). In SA, the anomalies of rainfall and temperature related to the PDO display a spatial distribution similar to the ENSO-related anomalies (Garreaud et al., 2009).

At higher latitudes south of $20^{\circ} \mathrm{S}$, the Southern Hemisphere Annular Mode (SAM), also referred to as the Antarctic Oscillation (AAO), influences climate variability at intermonthly and interannual timescales (Thompson and Wallace, 2000). The SAM is characterized by two pressure anomalies of opposite signs centered in Antarctica and a circumglobal band at $\sim 40-50^{\circ} \mathrm{S}$, related to the north-south displacement of the SWWs (Garreaud et al., 2009). In SA, the influence of this feature is associated with the increase in air temperature between 40 and $60^{\circ} \mathrm{S}$ and a decrease in precipitation in southern Chile during its positive phase, related to a southward shift of the SWWs (Thompson et al., 2000; Thompson and Solomon, 2002; Marshall et al., 2004; Garreaud et al., 2009).

In addition, due to its outstanding orographic features, the southwestern margin of SA could also be influenced by regional to local climate variations that are superimposed on these large-scale phenomena (e.g., Rutllant et al., 2003; Moy et al., 2009).

In the past decades, several changes have affected the climate of SA. The most important of these variations are a decrease in precipitation in southwestern SA (Boisier et al., 2016, 2018) and an intensification of coastal-upwellingfavorable winds (Schneider et al., 2017) that trigger biological and biogeochemical consequences (Anabalon et al., 2016; Aguirre et al., 2018). Several authors have associated changes in alongshore winds to an intensified or expanded SPSH (e.g., Falvey and Garreaud, 2009; Belmadani et al., 2014; Ancapichún and Garcés-Vargas, 2015).

These observed trends are also found in numerous model projections for warming scenarios, suggesting that these changes could continue during this century as a result of changes in the SPSH and precipitation, related to a poleward shift and intensification of the SWWs (e.g., Fyfe and Saenko, 2006; Ihara and Kushnir, 2009; Chavaillaz et al., 2013; Bracegirdle et al., 2018). The projection of a poleward displacement of the SPSH that intensifies alongshore winds at the poleward portions of upwelling systems is a clear and 
robust characteristic in south-central Chile (Rykaczewski et al., 2015). Furthermore, the upwelling system off southcentral Chile exhibits a robust future change in the timing, intensity, and spatial distribution of alongshore winds as a consequence of global warming (Belmadani et al., 2014; Wang et al., 2015; Rykaczewski et al., 2015).

\subsection{Late Holocene climate in South America: global events}

The LIA refers to a period of prominent climate anomalies over the past millennium when cold conditions were recorded in most of Europe and parts of North America. It has been established that the LIA developed between 16th and mid-19th centuries (Mann, 2002), being the last cold period recorded on Earth. However, the timing, magnitude, and nature of this event vary significantly from region to region (Bradley and Jones, 1993; Mann et al., 1999) and between archives (Chambers et al., 2014).

Unlike the Northern Hemisphere (NH), where the LIA is relatively well understood (e.g., PAGES2k Consortium, 2017), across the SH the evidence and detection of this phenomenon in proxy-climate records are less clear with respect to its timing, regional extent, and specific associated climatic changes (e.g., Chambers et al., 2014). The recent annually resolved millennial temperature reconstruction for the $\mathrm{SH}$ developed by Neukom et al. (2014) reveals a cold phase (1594$1677)$ coinciding with the peak of the LIA. However, at the regional scale, particularly in southern SA, evidence of this event has been poorly documented.

In general terms, the few reconstructions made suggest that in this region the LIA was a period characterized by wetter conditions related to changes in the position of the SWW belt (e.g., Lamy et al., 2001; Moy et al., 2008, 2009; Moreno et al., 2014). However, so far there is still no consensus about the trend in temperature during the LIA in this region. Some authors (e.g., Masiokas et al., 2009; Koch and Kilian, 2005; Koch, 2015) have recognized glacier advances in the extratropical SA $\left(17-55^{\circ} \mathrm{S}\right)$ during this period, which can be interpreted as cold conditions. However, recently González-Reyes (2019), based on glacier equilibrium line altitude modeling, determined that in the Mediterranean Andes $\left(30-37^{\circ} \mathrm{S}\right)$ there are no marked glacier advances associated with the "classic" (i.e., NH) LIA. Instead of that, the authors explain that more local factors, such as the Pacific SST variability, would have controlled the glacier mass balance in the region during this period.

Moreover, CMIP5/PMIP3 Last Millennium (LM) simulations have shown weak temperature anomalies during the LIA, hindering the identification of this period, especially in the SH (e.g., Rojas et al., 2016; Fig. S1). This has been associated with the fact that this global event is a response to internal climate variability (PAGES2k Consortium, 2013; Neukom et al., 2014) rather than to external forcing.
On the other hand, an increase in mean global temperature from the late 20th century has been observed and thoroughly documented by many authors (e.g., Jones et al., 1998, 2001; Mann et al., 1999, 2003; Briffa, 2000; Crowley and Lowery, 2000; Folland et al., 2001; Hartmann et al., 2013, among many others). This global warming, also referred to as the late 20th century warmth or the Current Warm Period (CWP), has been defined as a period of uniformly positive and simultaneous temperature trends in both hemispheres (e.g., Neukom et al., 2014), with no precedent in the last 1000 years (Mann et al., 1999; Jones et al., 1998, 2001; Crowley and Lowery, 2000; Folland et al., 2001; Jones and Mann, 2004; Marcott et al., 2013; Neukom et al., 2014; PAGES2k Consortium, 2017). This characteristic makes the CWP, together with the LIA, the major climate event of the past 1 or 2 millennia, a period known as the "late Holocene" (Williams and Wigley, 1983).

\section{Methodology}

\subsection{Climate models for the last millennium, the historical period, and 21st century projections}

In this study, we analyze open-access CMIP5/PMIP3 climate model experiments for which all three types of simulations are available: (1) the Last Millennium simulation (past1000; Schmidt et al., 2011, 2012), which considers observed forcing (orbital parameters, solar irradiance, greenhouse gases, land use change, and volcanic aerosols) covering the 850$1850 \mathrm{CE}$ period; (2) the historical simulation, which includes natural and anthropogenic (greenhouse gases concentration and aerosols) forcing over the 1850-2005 CE period; and (3) the anthropogenically forced Representative Concentration Pathway (RCP) 8.5 scenario (named for the equivalent effect in the radiative forcing by $2100 \mathrm{CE}$ relative to the preindustrial period: $+8.5 \mathrm{Wm}^{-2}$ ), characterized by increasing greenhouse gas emissions over the period 2006-2100 CE (21C). Four models meet these criteria (Table 1). For each of these, we use the first ensemble member (r1i1p1).

We particularly analyze different meteorological variables considered to be representative of the main climate components present over western South America. The variables analyzed correspond to monthly mean data for (a) the SPSH, represented by sea level pressure (SLP) and the position (latitude, longitude) of its maximum, (b) the intensity of the meridional winds (e.g., approximately alongshore) at $850 \mathrm{hPa}$, (c) the SWWs defined as the latitudinal position of the maximum zonal wind at $850 \mathrm{hPa}$ between 40 and $60^{\circ} \mathrm{S}$, (d) the Intertropical Convergence Zone (ITCZ) represented by the position of the maximum value of precipitation between $15^{\circ} \mathrm{N}$ and $8^{\circ} \mathrm{S}$, and (e) the subtropical jet (STJ) using the latitudinal position of the maximum zonal wind at $200 \mathrm{hPa}$ north of $48^{\circ} \mathrm{S}$. 
Table 1. Characteristics and definition of the LIA period for each model simulation used. Modified from Rojas et al. (2016).

\begin{tabular}{llll}
\hline Model & Horizontal resolution & LIA period & Reference \\
\hline bcc-csm-1 & $2.8^{\circ} \times 2.8^{\circ}$ & $1590-1790$ & Wu et al. (2014), Xin et al. (2013) \\
CCSM4 & $0.9^{\circ} \times 1.25^{\circ}$ & $1710-1810$ & Gent et al. (2011) \\
IPSL-CM5A-LR & $1.9^{\circ} \times 3.75^{\circ}$ & $1630-1710$ & Dufresne et al. (2013) \\
MRI-CGCM3 & $1.1^{\circ} \times 1.12^{\circ}$ & $1510-1620$ & Yukimoto et al. (2011) \\
\hline
\end{tabular}

Additionally, the global $\mathrm{HC}$ is computed over the three periods (LIA, CWP, 21C) using the mean meridional mass stream function.

\subsection{Global climate events: time periods considered}

For the LIA period, we use the time period identified in each model by Rojas et al. (2016), based on the annual temperature anomaly over the NH with respect to the 1000-1850 CE mean, and the meridional SST gradient between the tropical North and South Atlantic (Table 1). On the other hand, the definition of the onset of the CWP varies by author. Some of them consider it to be since 1850 CE (Deng et al., 2017) or the entire 20th century (1901-1990) (Briffa et al., 1995; Briffa, 2000; Jones et al., 1998), while other authors refer to the "mid-20th century" (e.g., Crowley and Lowery, 2000; Levitus et al., 2000) or the "late 20th century" (e.g., Mann et al., 2003; Jones and Mann, 2004; Osborn and Briffa, 2006). Recently, Díaz and Vera (2018) considered the CWP in South America to be the period between 1951 and $2000 \mathrm{CE}$, also taking into account the negative rainfall trend observed in the southern Andes.

According to the last IPCC Special Report (Allen et al., 2018), between 1890 and 2010 almost all the current warming could be attributed to human activities; in the absence of strong natural forcing, solar and volcanic contributions account for less than $\pm 0.1^{\circ} \mathrm{C}$ of the temperature increase between 1890 and 2010. The same report states that since 2000 , the human-induced warming accounts for $\sim 80 \%$ of total warming, with the $\pm 20 \%$ uncertainty attributed to solar and volcanic contributions.

Whatever the time period considered, all these studies have led to a consensus that in the past few decades, the mean annual NH temperatures are the warmest of the last 1000 or even 2000 years (PAGES2k Consortium, 2019). For this reason, we consider the CWP to be the period covering the years 1970-2000 CE.

Finally, in an analogous way, the RCP8.5 scenario in model projections for the end of the 21 st century was considered to cover the period between the years 2070 and 2100.

\subsection{Reanalysis data}

With the aim of comparing the CMIP5/PMIP3 simulation data for the CWP (historical experiment; 1970-2000) and the present-day climate observational dataset, we use an- nual and seasonal mean data from the ERA-Interim Reanalysis for the period 1979-2009. This project, extensively used in climate research, consists of a global-scale dataset that includes recorded climate observations of atmospheric weather (data available online at https://www.ecmwf.int/ en/forecasts/datasets/reanalysis-datasets/era-interim, last access: 30 March 2019), with a spatial resolution of approximately $0.75^{\circ} \times 0.75^{\circ}$ (latitude $\times$ longitude), for the most relevant meteorological variables (wind, pressure, temperature, and cloud cover, among others). Its primary temporal resolution is $3 \mathrm{~h}$ for surface parameters, starting in 1979 and being continuously updated in near-real time (Dee et al., 2011).

We use the ERA-Interim Reanalysis because of its high spatial resolution and the continuous improvement in the quality of the data.

\subsection{Climate records of southwestern South America}

In order to test the robustness of CMIP5/PMIP3 LM climate simulations, we carry out an integration of the results obtained from model simulations as well as paleoclimate and paleoenvironmental reconstructions of several regional highresolution records, mainly from southwestern South America but also from other regions of the world.

We consider records that (1) provide information about the main climate features affecting southwestern South America, (2) have a minimum length of 500 years to potentially record the LIA and the CWP, and (3) have a resolution at interannual to centennial timescales (Fig. 2).

The selected records fulfill at least three criteria defined in the PAGES2k network. However, we also include records that do not meet these criteria but are particularly valuable because of their temporal resolution or location, considering the sparseness of records in this region. Details of the selected records and their main characteristics are presented in Table 2.

\section{Results and discussion}

\subsection{Paleoclimate evidence}

Several paleoclimate records analyzed (Table 3, Fig. 2) indicate that important changes have occurred during the late Holocene along the western margin of South America. Salvatecci et al. (2014) analyzed marine laminated sediments off Pisco ( $14^{\circ} \mathrm{S}, 76^{\circ} \mathrm{W}$; Perú), interpreting a period of weak 
Table 2. List of paleoclimate and paleoenvironmental records from southern South America and other regions used in this work, along with their characteristics.

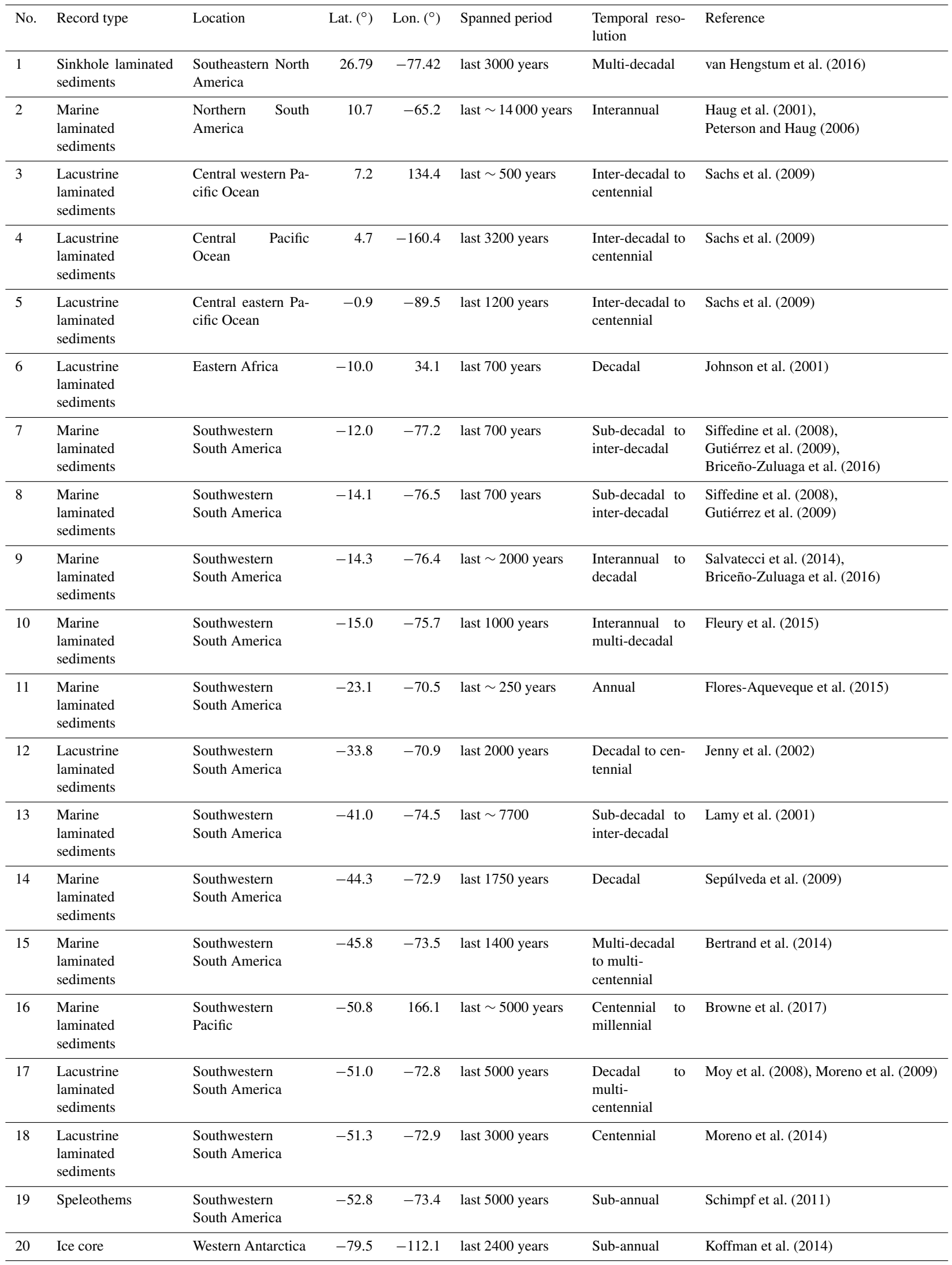




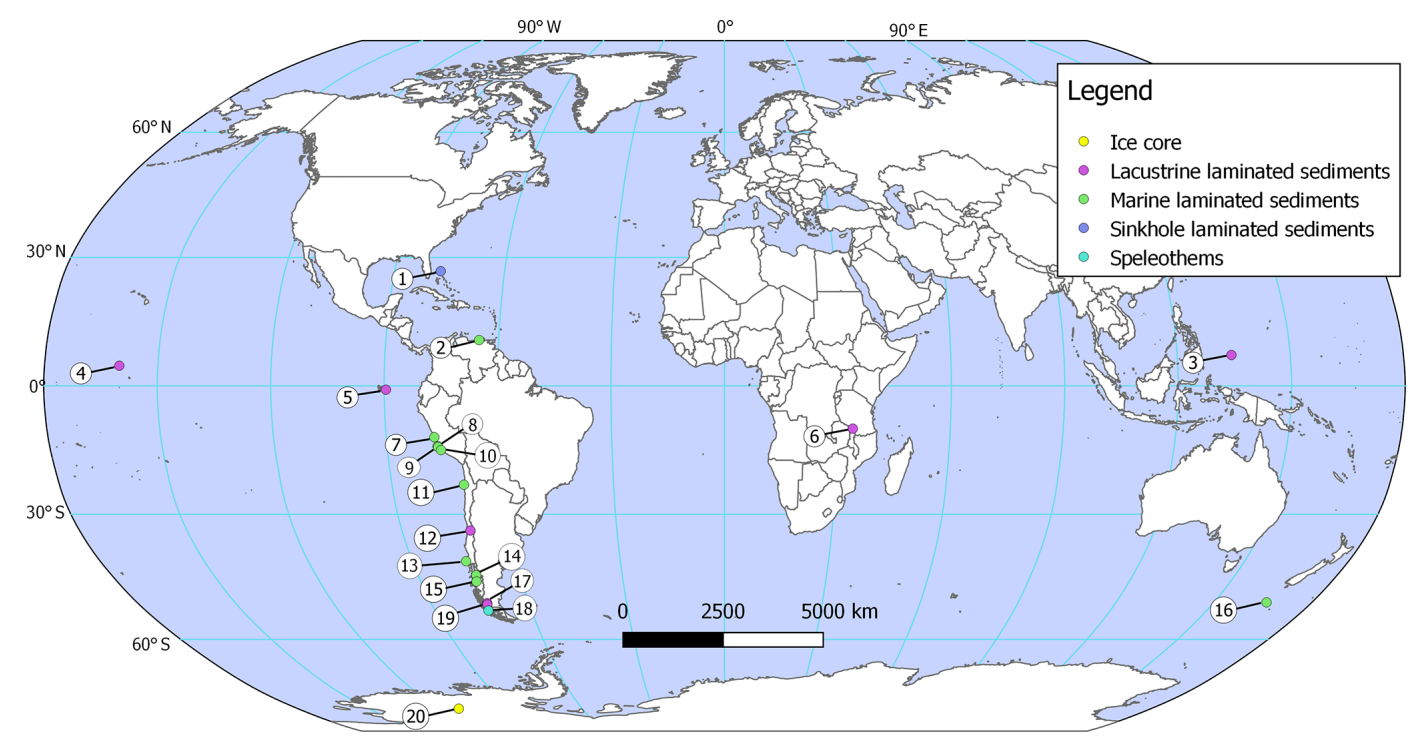

Figure 2. Global distribution of the paleoclimate and paleoenvironmental records used in this work. See Table 1 for number identification.

alongshore winds related to a contracted SPSH during the LIA and stronger winds due to an expanded anticyclone during the CWP. Recent climatological data seem to support these observations (Falvey and Garreaud, 2009).

In the same area and slightly further north (Callao at $12^{\circ} \mathrm{S}$, $77^{\circ} \mathrm{W}$; Fig. 2), Sifeddine et al. (2008) also noted an increase (decrease) in the intensity of southerly winds during the CWP (LIA) attributed to a strengthened (weakened) SPSH. These authors suggest that these conditions could be caused by changes in the ITCZ and the SPSH latitudinal position, both being displaced to the north (south) during the warm (cold) period. Changes in alongshore winds are also reported off central Peru by Gutiérrez et al. (2009) and Briceño-Zuluaga et al. (2016), as well as in northern Chile $\left(23^{\circ} \mathrm{S}, 70^{\circ} \mathrm{W}\right.$; Fig. 2) by Flores-Aqueveque et al. (2015), who interpreted the recent increase in southerly wind intensity trend as a response to an expanded and/or intensified SPSH. According to Gutiérrez et al. (2009) and BriceñoZuluaga et al. (2016), stronger winds could be related to a northward displacement of the ITCZ-SPSH system during the CWP and to an intensification of the Walker circulation associated with the current global warming. These authors also stated that during the LIA, the ITCZ was located southward of its modern position, agreeing with the interpretation by Fleury et al. (2015) for the same area $\left(11-15^{\circ} \mathrm{S}\right.$, Perú; Fig. 2). However, unlike the first authors, Fleury et al. (2015) noted a weakening in the Walker circulation since $1800 \mathrm{CE}$ that suggests the influence of additional processes, probably related to a secular positive trend in tropical SST, accounting for this decrease.

Latitudinal changes in the ITCZ mean position, with a southward displacement during the LIA, have also been recorded in other parts of the world such as the Cariaco Basin $\left(10^{\circ} \mathrm{N}, 66^{\circ} \mathrm{W}\right.$; Fig. 2$)$ in northern Venezuela (Haug et al.,
2001; Peterson and Haug, 2006), Washington Island $\left(4^{\circ} \mathrm{N}\right.$, $160^{\circ}$ W; Fig. 2), Palau ( $7^{\circ} \mathrm{N}, 134^{\circ}$ E; Fig. 2), and the Galápagos Islands $\left(1^{\circ} \mathrm{S}, 89^{\circ} \mathrm{W}\right.$; Fig. 2$)$ in the central Pacific (Sachs et al., 2009), Lake Malawi $\left(10^{\circ} \mathrm{S}, 34^{\circ} \mathrm{E}\right.$; Fig. 2) in eastern Africa (Johnson et al., 2001), and Abaco $\left(26^{\circ} \mathrm{N}, 77^{\circ} \mathrm{W}\right.$; Fig. 2) in the northern Bahamas (van Hengstum et al., 2016).

Changes in the South American climate system are also recorded at higher latitudes. Using lacustrine sediments of Laguna de Aculeo ( $33^{\circ} \mathrm{S}, 71^{\circ} \mathrm{W}$; Fig. 2), Jenny et al. (2002) observed an increase in precipitation in Mediterranean central Chile during the LIA and interpreted it as an intensification of the SWWs. For the same period but using marine laminated sediments of southern Chile ( $41^{\circ} \mathrm{S}, 74^{\circ} \mathrm{W}$; Fig. 2$)$, Lamy et al. (2001) also noted an increase in precipitation in the southern Andes related to a northward displacement of the SWWs due to a weakened SPSH. The opposite occurs during a warm period, such as the Medieval Climate Anomaly (MCA).

Further south, Sepúlveda et al. (2009) reported a northward shift of the SWW belt during the LIA, according to a marine sedimentary record obtained from the Jacaf Fjord in northern Chilean Patagonia ( $44^{\circ} \mathrm{S}, 73^{\circ} \mathrm{W}$; Fig. 2). The same is interpreted from the analysis of a sediment core of Quitralco Fjord $\left(46^{\circ} \mathrm{S}, 73^{\circ} \mathrm{W}\right.$; Fig. 2) by Bertrand et al. (2014), who found that during the LIA (1200-1500 CE), the SWWs were gradually shifted northward and slightly moved poleward during the last decades, agreeing with recent trends in observed climatological data (e.g., Shindell and Schmidt, 2004). According to these authors, late Holocene variations (latitudinal position and extent) in the SWWs were mostly driven by changes in the strength of the polar cell, which responds to changes in temperature at higher latitudes in the SH; this is in opposition to Lamy et al. (2001), who explained the changes in the SWWs based 


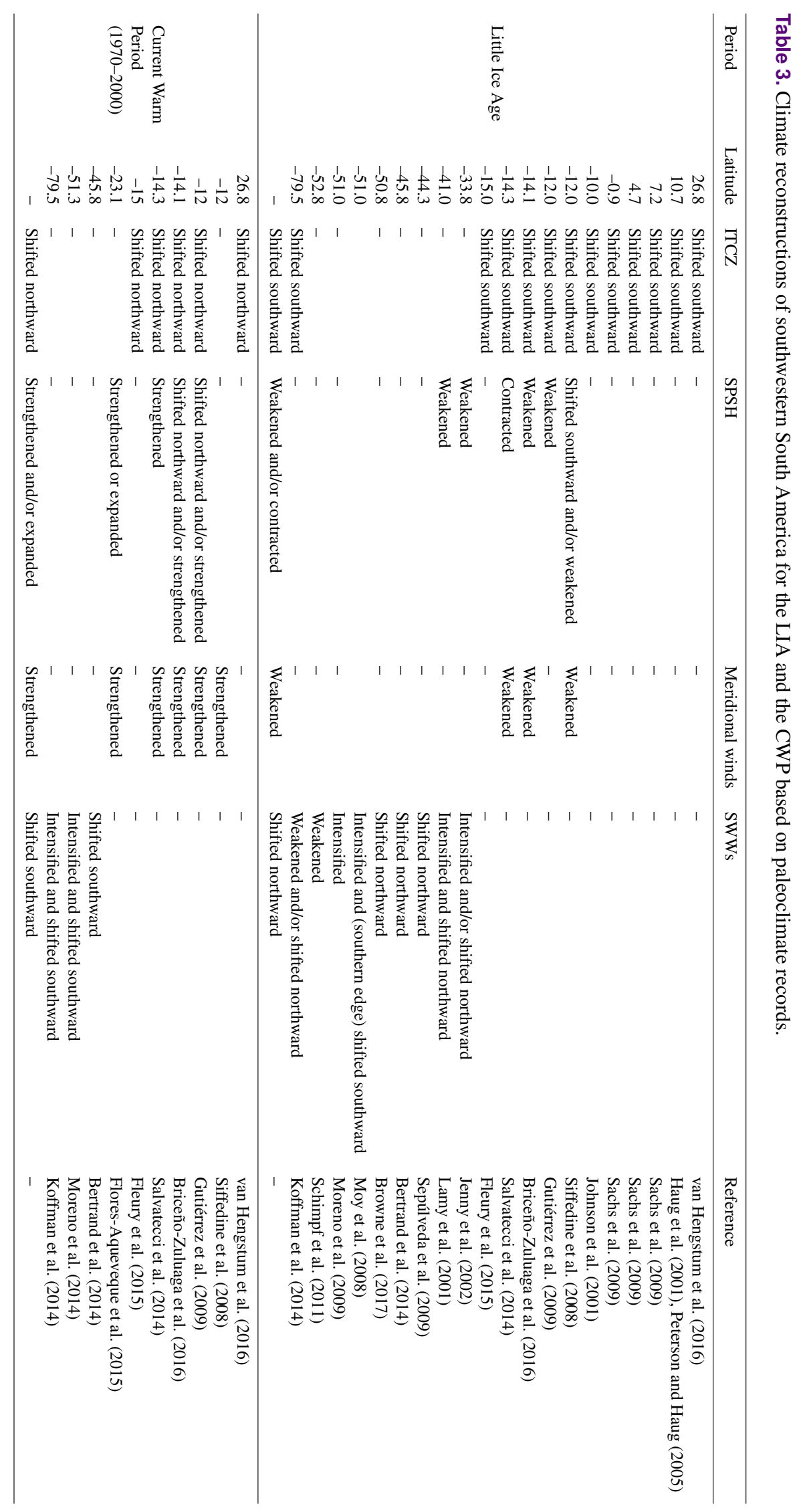


on variations in the tropical climate system (i.e., Hadley cell intensity).

Evidence of SWW variations is also observed in paleoclimate records at subantarctic and Antarctic latitudes. The analyses of lacustrine sediments from Lago Guanaco, southwestern Patagonia ( $51^{\circ} \mathrm{S}, 73^{\circ} \mathrm{W}$; Fig. 2), developed by Moy et al. (2008) and Moreno et al. (2009) indicate that precipitation increased during the LIA, related to more intense westerly winds. Moy et al. (2008) also suggest a poleward shift of the southern margin of the SWW belt synchronously with this intensification.

On the other hand, Schimpf et al. (2011) noted a decrease in precipitation during the LIA and interpreted it as a southward shift or a weakening in the core of the SWWs, according to a stalagmite from the southernmost Andes $\left(53^{\circ} \mathrm{S}\right.$, $73^{\circ}$ W; Fig. 2). Recently, Browne et al. (2017), based on a fjord sediment core collected from the Auckland Islands $\left(51^{\circ} \mathrm{S}, 166^{\circ}\right.$ E; Fig. 2), interpreted a northward (southward) shift of the SWWs during the LIA (MCA), suggesting that the synchronous changes in the SWWs observed on both sides of the Pacific could be controlled by atmospheric teleconnections between the low and high latitudes, modulated by the variability in the AAO and ENSO. Finally, Koffman et al. (2014), based on dust particles found in an ice core from western Antarctica ( $79^{\circ} \mathrm{S}$; Fig. 2), interpreted the SWWs to be less (more) intense and/or displaced equatorward (poleward) during the cold (warm) period in response to both surface temperature changes in the tropical Pacific and solar variability.

The apparent incongruity of the SWW changes observed among paleorecords could be partly explained by their locations. Thus, the different proxies could be recording differential changes in the wind intensity between the edges and the core and/or latitudinal displacements of this belt.

\subsection{Model simulations vs. present-day atmospheric observations}

The analysis of the main present-day (1979-2009) climate features of southwestern SA from ERA-Interim shows that some differences arise when comparing this dataset (Fig. 1a) with model simulations for a comparable period (19702000) (Fig. 1b). In general terms, the four models analyzed here seem to underestimate the present-day SPSH extension, especially during austral summer (DJF) when the reanalysis shows an SPSH more expanded than simulated conditions. With respect to the location of the SPSH, it can be noted that although the latitudinal SPSH position is very similar in both datasets, major differences can be observed in its longitudinal position (Table S1 in the Supplement). Maximum values of the SLP in reanalysis data are located further west than those of the models at annual and seasonal scales, with this difference being more remarkable during austral summer, reaching around $11^{\circ}$ of longitude.
The position of the STJ is another climate feature that differs between the reanalysis and climate models. For reanalysis data, the latitudinal position of the STJ when it reaches the continent is around $27^{\circ} \mathrm{S}$ during the austral winter and $29^{\circ} \mathrm{S}$ in the annual mean (Fig. 1a), being between $3^{\circ}$ and $6^{\circ}$ of latitude north, respectively, of those represented by historical simulations (i.e., $\sim 30^{\circ} \mathrm{S}$ during austral winter and $\sim 35^{\circ} \mathrm{S}$ in the annual mean) (Fig. 1b). According to the results obtained by Hudson (2012), the SH STJ position varied between $\sim 30^{\circ}$ and $\sim 45^{\circ} \mathrm{S}$ between 1979 and 2010. This range is in good agreement with the values obtained from climate models, suggesting that the ERA-Interim reanalysis dataset underestimates the STJ meridional position.

At higher latitudes, ERA-Interim reanalysis data differ from models in the representation of the present-day behavior of the SWWs (Fig. 1), indicating a position further south of its core when this wind belt meets the continent $\left(\sim 54^{\circ} \mathrm{S}\right)$ during the entire year, showing almost no seasonal differences. Similar results are obtained by Swart et al. (2015), who compared surface winds and satellite-based data, finding that several reanalyses overestimate recent observed trends. Moreover, these authors also found that spurious long-term trends in SLP and winds observed in diverse reanalysis datasets for the $\mathrm{SH}$, especially in the southeastern Pacific, limit their applicability as a tool for validating these features in model simulations.

\subsection{Climate changes over southwestern South America since the late Holocene according to GCMs}

Figure 3 shows the difference between the meridional winds during the LIA and the CWP (LIA minus CWP) for each model as well as for the four-model mean. In addition, the position of the ITCZ, the upper-level STJ, the SWWs at $850 \mathrm{hPa}$, and the SPSH locations for the LIA (cyan line) and the CWP (fuchsia line) are displayed.

The four-model ensemble annual as well as the austral summer and winter means show a strengthening of the SPSH during the warm period, expressed as an expansion of this high-pressure center, mainly to the west and south. This trend is also observed in individual models, except for the austral winter conditions and consequently the annual mean of model MRI-CGCM3. The SPSH expansion is more evident when comparing CWP and 21C data (Fig. 4), with its southern rim reaching higher latitudes as temperature increases. This behavior was already noted by Garreaud and Falvey (2009) using the PRECIS R2A regional climate model, and Kitoh et al. (2011) in high-horizontal-resolution (20 and $60 \mathrm{~km}$ grid) model projections. The opposite (i.e., a contracted SPSH) is observed during relatively colder periods, except for the austral winter (June-July-August; JJA), when the SPSH positions for the LIA and the CWP are nearly identical (Fig. 3).

With respect to the SPSH position, major differences can be observed in latitude between austral summer (December- 


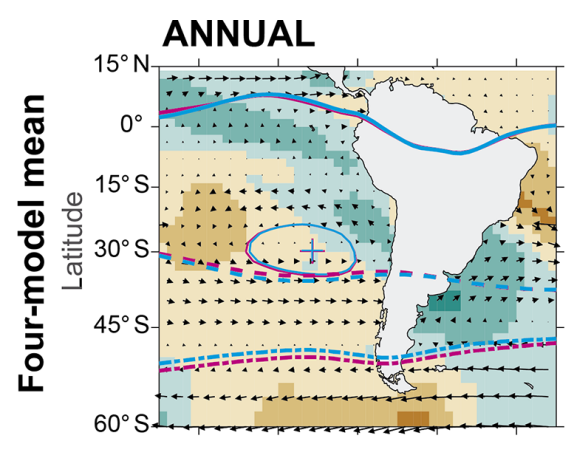

\section{DJF}
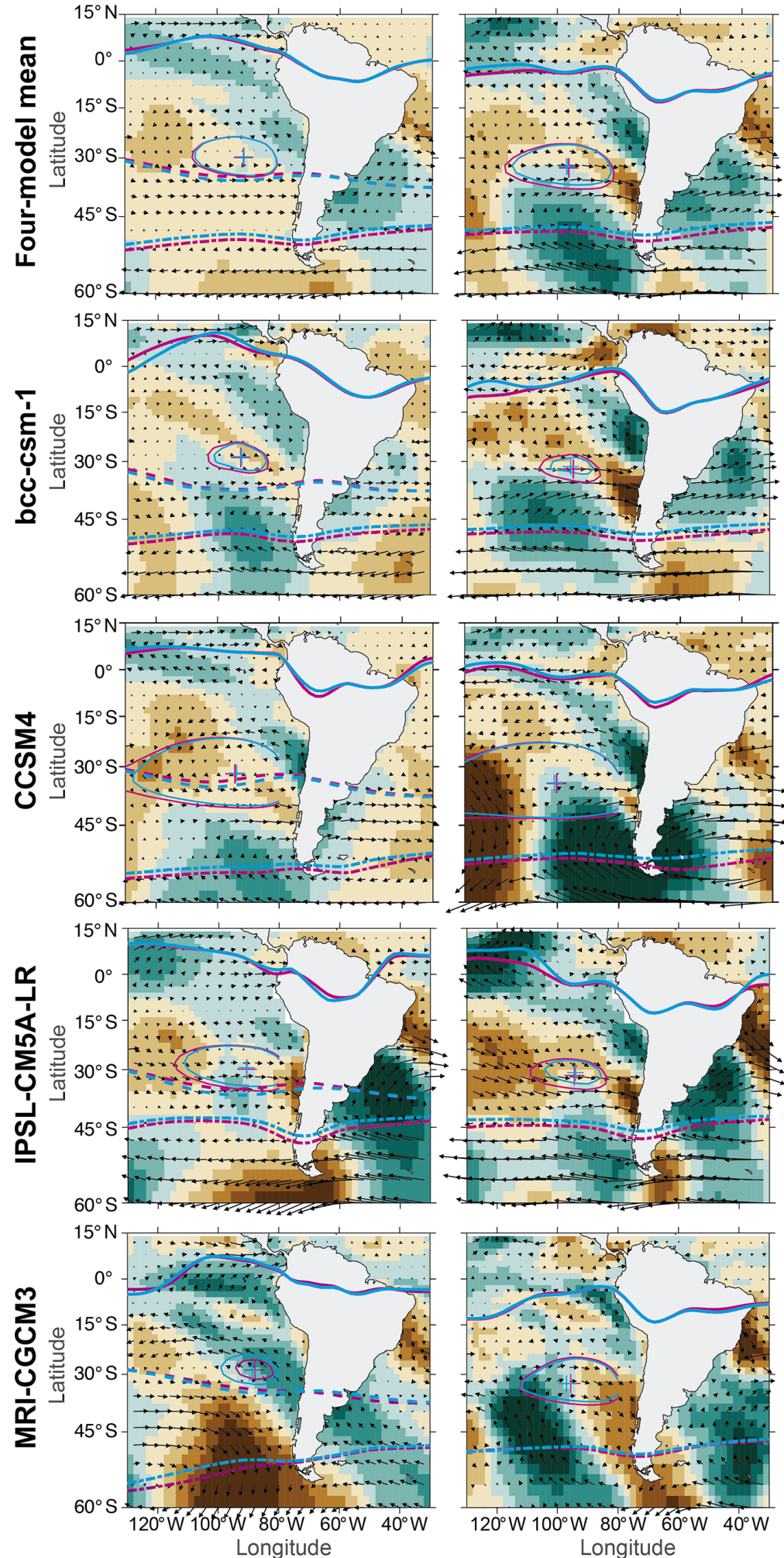
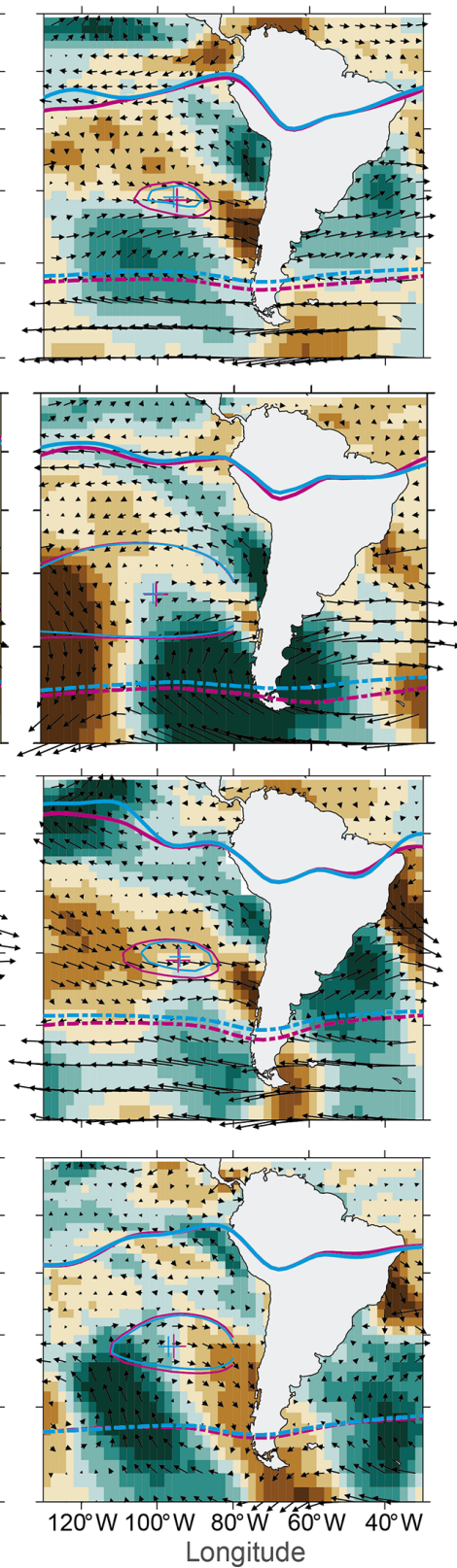

JJA
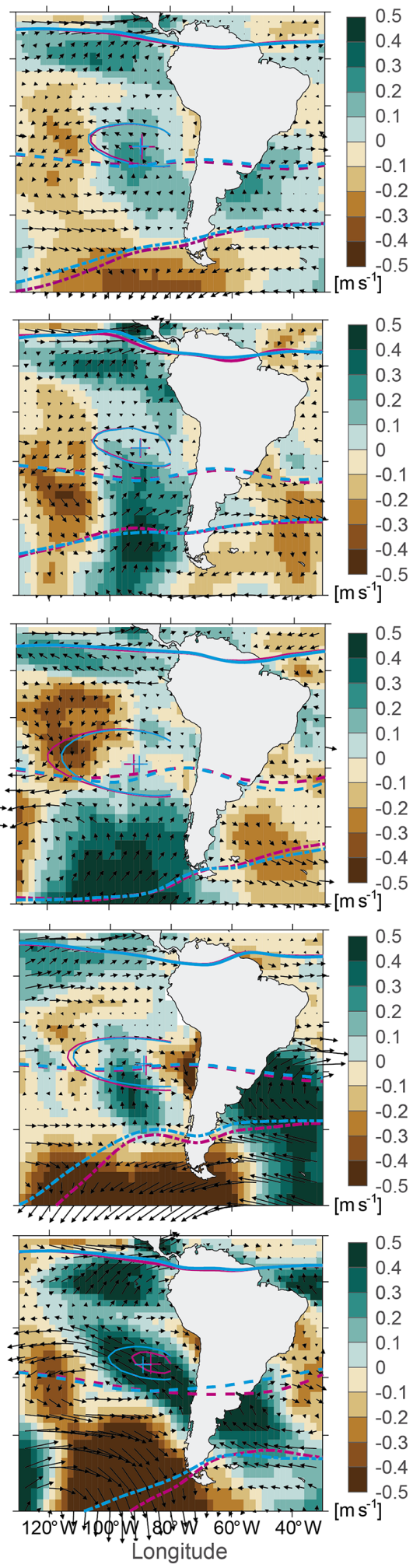

Figure 3. Annual and seasonal means of the southwestern South American climate system during the LIA (cyan lines) and the CWP (fuchsia lines) for the four-model mean and for each model. Background colors and vectors show the meridional wind difference LIA minus CWP. DJF: austral summer, JJA: austral winter, ITCZ: Intertropical Convergence Zone (thick solid lines), SPSH: Subtropical South Pacific High (thin solid lines), STJ: subtropical jet (dashed lines), SWW: southern westerly winds (dash-dotted lines). Crosses indicate the location of maximum SLP over the SPSH (i.e., SPSH location). 


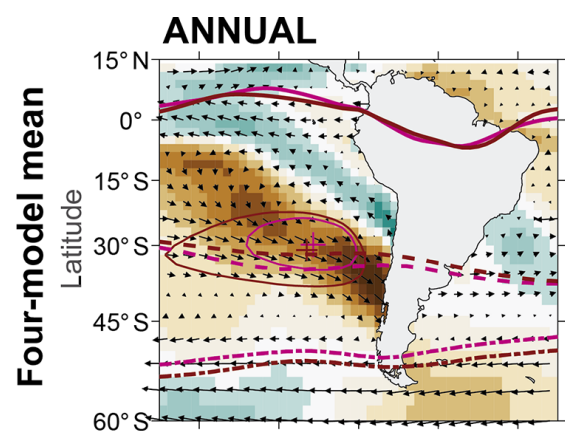

\section{DJF}
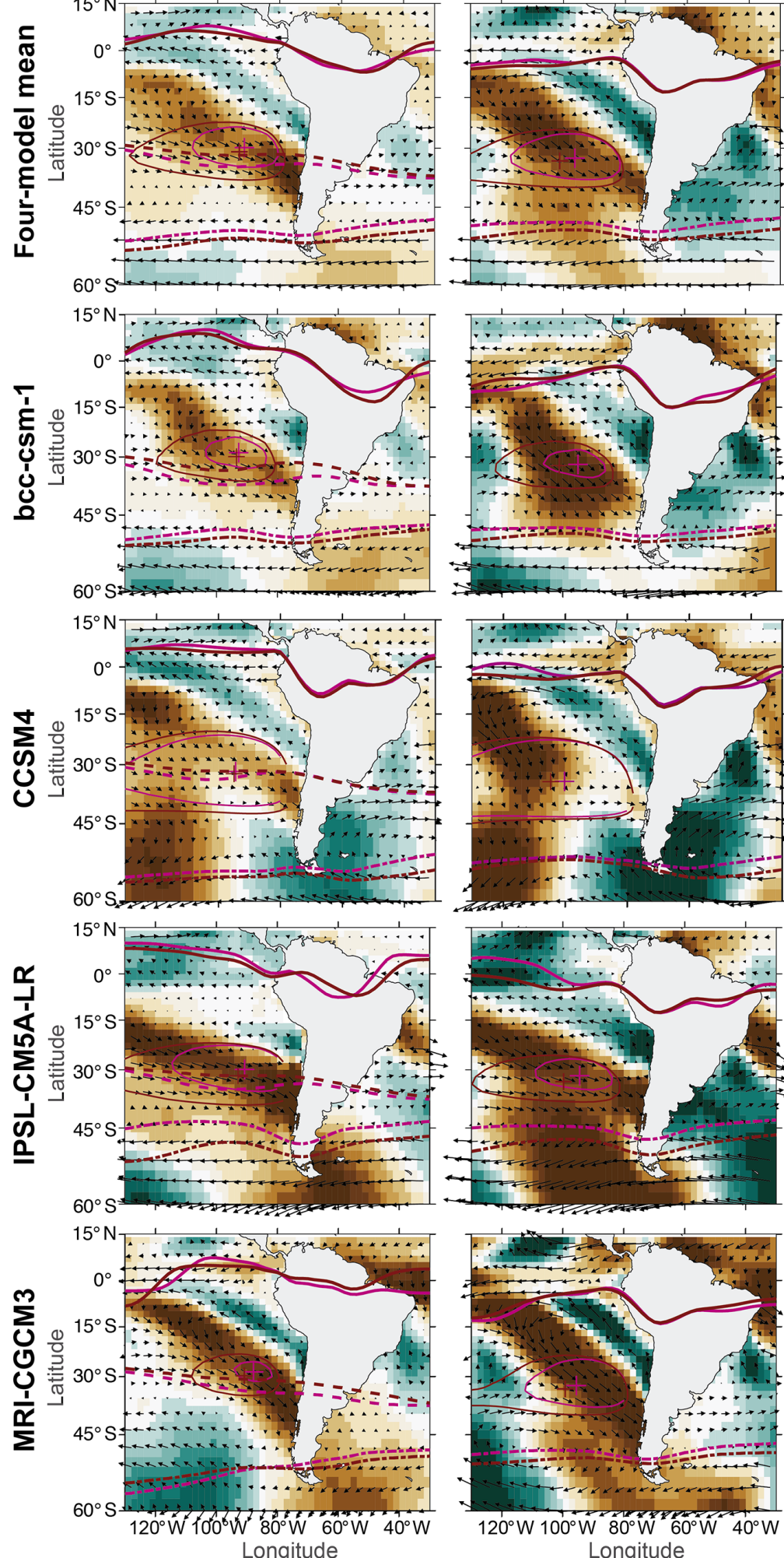
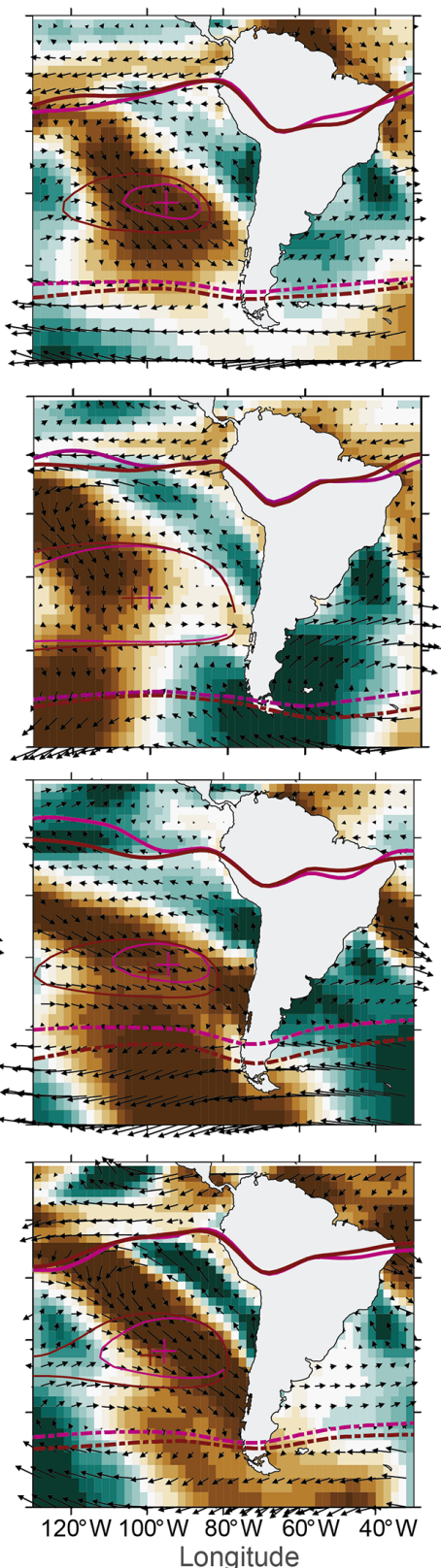

JJA
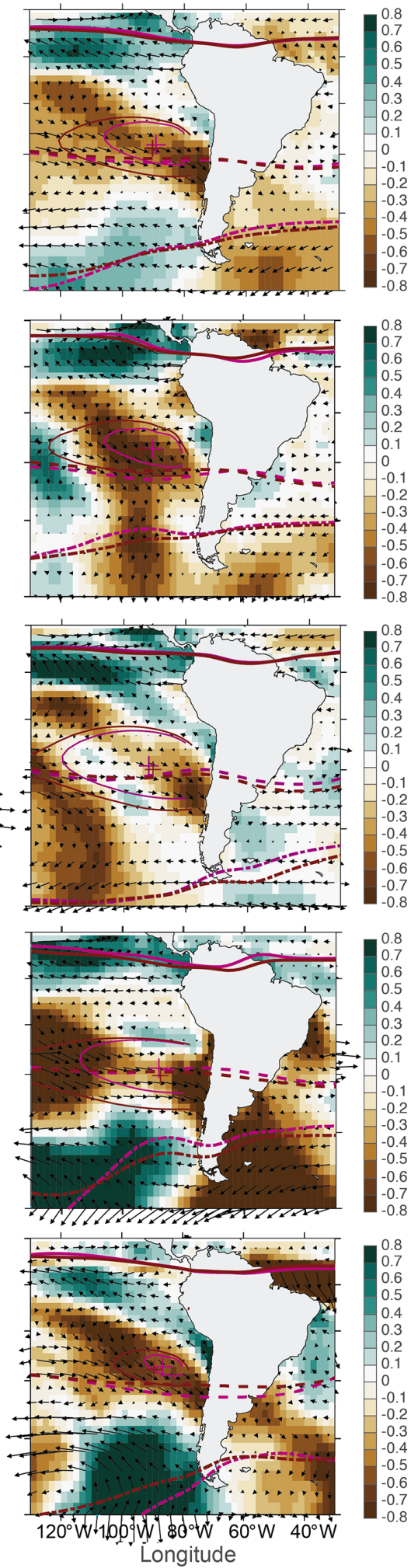

Figure 4. Annual and seasonal means of the southwestern South American climate system during the CWP (fuchsia lines) and 21C (dark red lines) for the four-model mean and for each model. Background colors and vectors show the meridional wind difference CWP minus 21C. DJF: austral summer, JJA: austral winter, ITCZ: Intertropical Convergence Zone (thick solid lines), SPSH: Subtropical South Pacific High (thin solid lines), STJ: subtropical jet (dashed lines), SWW: southern westerly winds (dash-dotted lines). Crosses indicate the location of maximum SLP over the SPSH (i.e., SPSH location). 
January-February; DJF), when the maximum atmospheric pressure is located on average at $\sim 33^{\circ} \mathrm{S}$, and austral winter (JJA) when it moves northward at $\sim 27.5^{\circ} \mathrm{S}$ (Table S1 in the Supplement). This behavior agrees with the seasonal variation observed by Rahn and Garreaud (2013) using the Climate Forecast System Reanalysis (CFSR) data for the period 1979-2010 and by Barrett and Hameed (2017) using NCEP/NCAR reanalysis data for 1980-2013. The southward migration of the SPSH during austral summer would be attributable to a basin-wide increase in SLP around $40^{\circ} \mathrm{S}$ induced by changes in the latitudinal position of the ITCZ and the presence of the South American monsoon (Rodwell and Hoskins, 2001).

Longitudinal changes are also seen at a seasonal scale, with maximum values of SLP located at $\sim 98^{\circ} \mathrm{W}$ during austral summer (DJF) and moving eastward in austral winter (JJA) at $\sim 89^{\circ} \mathrm{W}$ on average (Table S1 in the Supplement). These values are close to those obtained by Rahn and Garreaud (2013) and Ancapichún and Garcés-Vargas (2015). The latter authors, using monthly NCEP/NCAR reanalysis data for the period 1949-2012, determined that over the past decade, the SPSH has intensified (at a rate of $1.36 \mathrm{hPa}$ per decade) and shifted towards the southwest, with its maximum located at $\sim 37^{\circ} \mathrm{S}$ and $\sim 108^{\circ} \mathrm{W}$ during February and March when the SPSH intensity is maximum. In contrast, during May, when the SPSH shows its weakest intensity, it is located further north $\left(\sim 26^{\circ} \mathrm{S}\right)$ and closest to the continent $\left(\sim 86^{\circ} \mathrm{W}\right)$. However, these observations are not in agreement with results from Barrett and Hameed (2017), who reported higher SLP values during austral spring (September to November) and an eastward migration during austral summer, whereas weaker values and a westward shift are observed in austral autumn (March to May). Since both works use the NCEP/NCAR reanalysis, this discrepancy could arise from the different methodologies used in each study to calculate the SPSH position and/or the different periods studied.

Nevertheless, from our results it should be highlighted that, regardless of seasonality, as temperature increases, a poleward and westward shift of the maximum value of SLP is observed, following the expansion trend. This coincides with Gillett and Fyfe (2013), Rykaczewski et al. (2015), and Lu et al. (2007), who indicated that higher values of SLP would tend to move poleward in response to increased greenhouse gas concentrations.

The SPSH expansion during the CWP period is accompanied by stronger (weaker) southerly winds south (north) of $\sim 35^{\circ} \mathrm{S}$ on the southeastern side of the anticyclone during the austral summer. In austral winter, the opposite situation develops, with an intensification of the coastal alongshore winds in northern to central Chile and a reduction of the intensity south of $\sim 35^{\circ} \mathrm{S}$ (Fig. 3). This phenomenon is observed systematically in each model. This effect could be explained by the fact that the SPSH expands to midlatitudes and shows no significant changes at subtropical latitudes, producing an enhanced meridional pressure gradient that leads to a strengthening of the low-level coastal jet (Garreaud and Falvey, 2009).

Wind intensity changes are also described by Belmadani et al. (2014), who analyzed the effect of global warming on the upwelling-favorable winds along the Peruvian and Chilean coast by using the Laboratoire de Météorologie Dynamique (LMDz; Hourdin et al., 2006) global circulation model downscaled to a resolution of $0.5^{\circ} \times 0.5^{\circ}$. According to these authors, the increase in the alongshore winds from central to southern Chile is related to a poleward shift and/or an intensification of the maximum latitudinal pressure gradient associated with similar changes in the SPSH or the HC.

A similar trend, but of less magnitude, is observed when comparing present-day and future conditions (Fig. 4). This result is consistent with the study of Garreaud and Falvey (2009), who point out that the strengthening of the alongshore wind speed will continue throughout the 21 st century. This reinforcement is characterized by a marked seasonality in which stronger meridional winds occur between 37 and $41^{\circ} \mathrm{S}$ during austral spring-summer and migrate to subtropical latitudes in the austral fall-winter season as a result of an important increase in SLP (2-3 hPa) developed towards the southern rim of the SPSH. The authors also stated that by the end of this century, austral spring atmospheric coastal jet events will be more frequent and longer in duration that present-day events.

These results also agree with the hypothesis of Rykaczewski et al. (2015). This hypothesis postulates that the anthropogenic influence on seasonal changes and shifts in the geographic position of the major atmospheric highpressure centers will affect the intensity of upwellingfavorable winds.

On the other hand, models fail in representing the position and variations of the upper-level STJ, which is displaced to the north as the temperature increases (Figs. 3 and 4). This contradicts not only the general tendency of climate models of a poleward shift under the current global warming (e.g., Meehl et al., 2007; Woollings and Blackburn, 2012), but also findings from recent observations. In fact, the analysis of total ozone measurements from satellite and sounding data discussed by Hudson (2012) estimates a poleward displacement of the STJ of $3.7 \pm 0.3^{\circ}$ latitude in the $\mathrm{NH}$ and $6.5 \pm 0.2^{\circ}$ latitude in the SH between 1979 and 2010.

Changes in the SPSH also affect higher latitudes. As can be seen in Figs. 3 and 4, the expansion (contraction) of the SPSH observed during relative warmer (colder) periods coincides with a southward (northward) displacement of the core of the SWWs. This is valid for both seasons and the annual mean of each individual model as well as the four-model mean, except for the austral winter of model MRI-CGCM3 (Fig. 4). In addition, the SWWs are also stronger (weaker) during warmer (colder) periods (not shown). Therefore, an expanded SPSH acts to "block" the SWW belt, shifting it southward. This behavior is observed at annual and seasonal mean scales, being more pronounced during austral summer. 
This is in agreement with Garreaud et al. (2009), who used meteorological station and atmospheric reanalysis, and Swart et al. (2015), who considered 30 CMIP5 models and six reanalysis datasets. Garreaud et al. (2009) also pointed out that a contraction (expansion) of this wind belt occurs in parallel with southward (northward) seasonal shifts. However, since we only analyzed the position of its core, this feature cannot be observed from our results.

At longer timescales, Toggweiler et al. (2009) highlighted the general relationship between the position of the westerlies and global temperature. According to these authors, under warm conditions (e.g., the CWP), the SWWs shift poleward, while in cold climate periods (e.g., the Last Glacial Maximum), the westerlies move equatorward due to an increase in sea ice around Antarctica (Bentley et al., 2009). This northward shift could in turn "block" the SPSH, limiting its expansion and southward displacement. A similar effect could be produced by an increase in SWW intensity as a result of a decrease in the latitudinal thermal gradient or due to an increased pressure gradient related to the differential heating between SA and the South Pacific.

The southward migration, together with the increase in its core strength, experienced by the SWWs during the last decades has been related to the shift to an increasingly positive phase of the SAM (e.g., Thompson et al., 2000; Thompson and Solomon, 2002; Marshall et al., 2004; Garreaud et al., 2009; Swart and Fyfe, 2012) as a response to changes in stratospheric ozone and greenhouse forcing (Thompson and Solomon, 2002; Gillett and Thompson, 2003; Shindell and Schmidt, 2004; Ihara and Kushnir, 2009; Son et al., 2010; Gillett and Parker, 2013). This confirms what was previously stated by Pittock (1980) and Aceituno et al. (1993), who proposed that the position of the SWWs depends on the location of the SPSH and the circum-Antarctic low-pressure belt.

The trend in the SWWs is also observed in several model projections for the 21st century, which highlight the tendency toward a poleward shift and an intensification of the SWWs related to anthropogenic global warming (e.g., Fyfe and Saenko, 2006; Ihara and Kushnir, 2009; Kitoh et al., 2011; Chavaillaz et al., 2013; Bracegirdle et al., 2018).

Changes associated with SWW variations have already shown visible effects in southern SA as an increase in desertification in northern Chile (Salinas and Mendieta, 2013; Ortega et al., 2019) and a notable decrease in annual precipitation from central Chile to central Patagonia (Boisier et al., 2018), exhibiting important impacts on socioeconomic activities in this region. Moreover, our results suggest that consequences related to SWW changes during the next decades, not only in southern SA (e.g., Vera et al., 2006; Meehl et al., 2007) but also at a global scale, for example through the release of $\mathrm{CO}_{2}$ from the Southern Ocean to the atmosphere (e.g., Menviel et al., 2018; Saunders et al., 2018), could be expected.

Summarizing, our results show that the numerical simulations analyzed here are consistent among themselves and generally in good agreement with other models (e.g., Garreaud and Falvey, 2009; Kitoh et al., 2011; Belmadani et al., 2014; Swart et al., 2015) as well as different sets of reanalysis data (e.g., Barrett and Hameed, 2007; Garreaud et al., 2009; Rahn and Garreaud, 2013; Ancapichún and GarcésVargas, 2015). A comparison of our results with these previous studies indicates that the models that we have considered represent the SPSH behavior, alongshore winds, and SWW changes well. However, simulations fail to represent the position of the STJ and its variations. The possible causes of this discrepancy will be explored in the next section.

\subsection{The link between the ITCZ and SPSH changes}

Different paleoclimate studies have linked changes in the ITCZ-SPSH system to variations in the SPSH (Sifeddine et al., 2008; Gutiérrez et al., 2009; Briceño-Zuluaga et al., 2016; Fleury et al., 2015; Flores-Aqueveque et al., 2015). To evaluate the role of the ITCZ in SPSH changes, we analyze the position of the ITCZ during the three considered periods. Figure $1 \mathrm{~b}$ shows that, in general, model simulations represent an ITCZ that is located north of the Equator $\left(\sim 10^{\circ} \mathrm{N}\right)$ during austral winter (JJA) and moves southward $\left(\sim 5^{\circ} \mathrm{S}\right)$ in austral summer (DJF). This range is very similar to the observed present-day conditions, in which the ITCZ is displaced seasonally from $9^{\circ} \mathrm{N}$ to $2^{\circ} \mathrm{S}$ (Denniston et al., 2016). However, according to Schneider et al. (2014), the ITCZ moves between $9^{\circ} \mathrm{N}$ in austral winter (JJA) and $2^{\circ} \mathrm{N}$ in austral summer (DJF) over the central Atlantic and Pacific oceans, suggesting that the considered models locate the ITCZ further south of its present-day position, especially in austral summer. In fact, the bias of global models representing the ITCZ and its different causes has been widely discussed in the literature (e.g., Hwang and Frierson, 2013; Hirota and Takayabu, 2013; Colas et al., 2012; Gordon et al., 2000; Ma et al., 1996).

In Figs. 3 and 4, it can also be observed that, generally, the ITCZ shifts southward over the Pacific as temperature increases at annual and seasonal scales, with this difference being more marked during austral summer. Over the Atlantic, in general, the opposite occurs: the ITCZ migrates slightly to the north during the $21 \mathrm{C}$ (Fig. 4), but it does not exhibit significant differences between the LIA and the CWP (Fig. 3). Furthermore, we analyze the meridional mass stream function (as a proxy for the HC strength) and the zonal mean precipitation during the LIA and the CWP (Fig. 5). Our results show a southern branch of the $\mathrm{HC}$ that intensifies during the cold period (LIA) and weakens in the current period at annual and seasonal scales. In addition, no evident shifts of the northern and southern $\mathrm{HC}$ branches are observed between the two periods. Generally, a similar feature is observed in all models but with different magnitude (Fig. S2).

A comparison of the intensity of the precipitation rate between the LIA and the CWP indicates no significant differences between periods. However, as can be noted in Fig. 5, the maximum precipitation during the CWP is slightly higher 

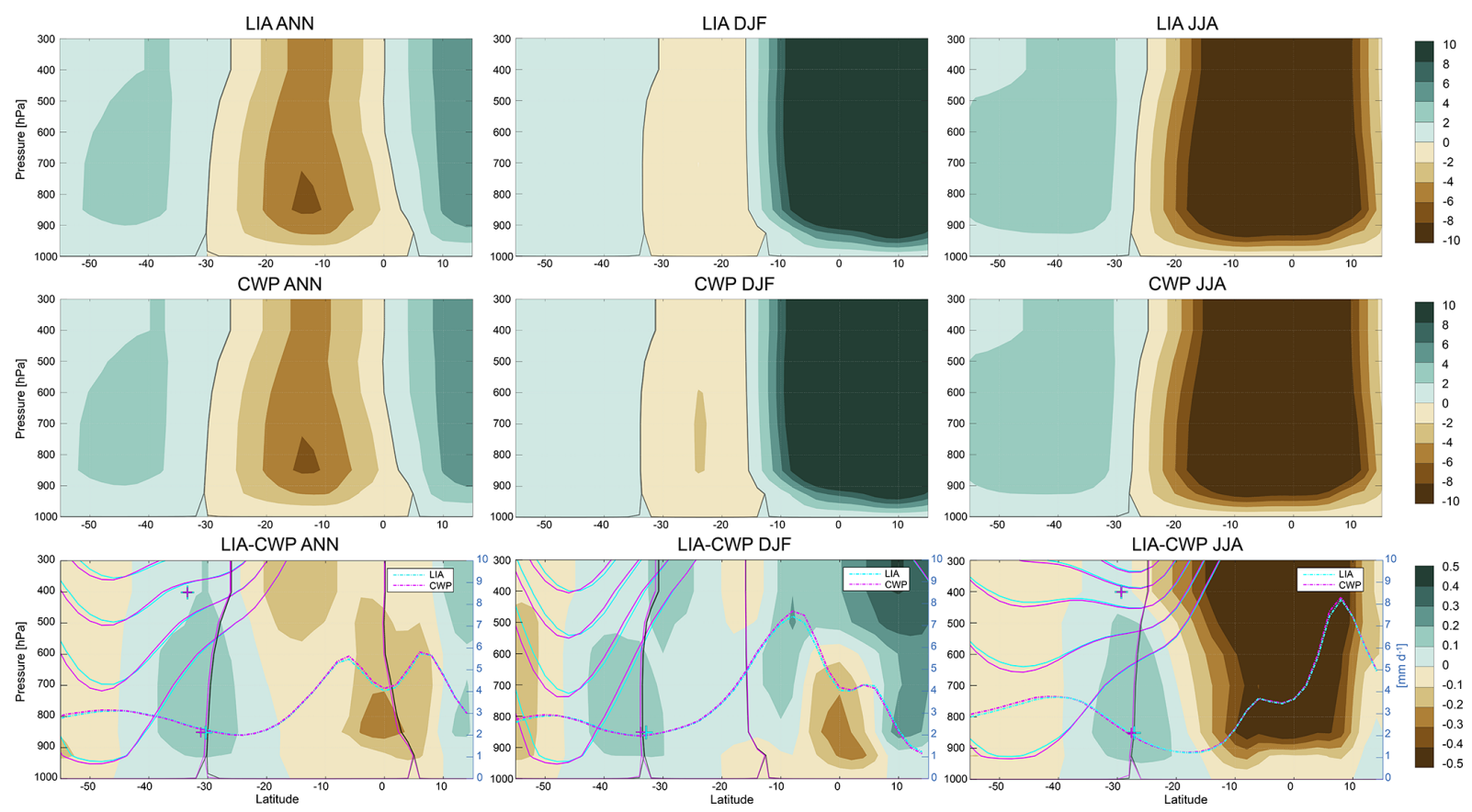

Figure 5. Mass stream function ensemble mean during the LIA, CWP, and LIA-CWP (shades) for the annual mean (ANN), austral summer (DJF), and austral winter (JJA). The zonal mean precipitation (dash-dotted lines), zonal mean winds (solid lines), subtropical ridge position (lower crosses), and latitude of maximum zonal winds at $200 \mathrm{hPa}$ (upper crosses) during the LIA (cyan) and the CWP (magenta) are also shown.

than in the LIA. In addition, zonal winds at $200 \mathrm{hPa}$ show almost no differences between the LIA and the CWP but appear to be located southward (equatorward) during the warm (cold) period. Similar results were obtained for each individual model (Fig. S2).

These results contradict the mechanism proposed by Lee et al. (2011), which states that the ITCZ moves southward and the southern branch of the HC becomes weaker, decreasing the intensity of the STJ, as a response to NH (i.e., North Atlantic) cooling. These authors indicate that a colder $\mathrm{NH}$ increases the north-south surface pressure interhemispheric gradient, driving an anomalous southward equatorial flow and shifting the annual mean position of the ITCZ southward. According to Sachs et al. (2009), this shift would have reached its southernmost position, of up to $500 \mathrm{~km}$, during the LIA (1400-1850 CE).

According to the literature, the ITCZ has shown important changes during the LM. Regarding the ITCZ position, Schneider et al. (2014) stated that during the LIA, the ITCZ experienced a southward shift, explained by a cooling of the $\mathrm{NH}$ extratropics relative to its southern counterpart. However, this shift is not always supported by this mechanism. The same authors indicate that ITCZ migrations are modulated by ENSO. In fact, during the transition from La Niña to El Niño, or during strong El Niño events, the NH extratropics warm around $0.08^{\circ} \mathrm{C}$ more than the $\mathrm{SH}$ extratropics (Hansen et al., 2010), but contrary to what should be ex- pected, the ITCZ moves southward. Schneider et al. (2014) justify this behavior considering variations in the tropical net energy input to the atmosphere. Slight changes in the atmospheric energy flux can produce substantial ITCZ migrations, with this sensitivity being one of the possible explanations for the difficulty that current climate models have in simulating the ITCZ position (Schneider et al., 2014).

On the other hand, Yan et al. (2015), based on paleohydrology records of the western Pacific and climate models, proposed that during the LIA the tropical rain belt (i.e., the latitudinal range over which the ITCZ seasonally moves) contracted, instead of a meridional shift as has been previously described (e.g., Lee et al., 2011). More generally, these authors proposed that over the western Pacific, the ITCZ expands and contracts over decadal to centennial timescales in response to external forcing, rather than showing a latitudinal migration. The same is observed by the analysis of stalagmites in southern China discussed by Denniston et al. (2016), who pointed out that the latitudinal movement range of the ITCZ expanded and contracted during the last 3000 years in a process that operates at multidecadal to centennial scales.

Reanalysis data for the 20th century also support the idea that the ITCZ does not migrate significantly with climate changes. In this sense, D' Agostino and Lionello (2016) indicated that since 1979, the ITCZ has shown no significant trend. However, they observed that the southern branch of the $\mathrm{HC}$ migrates southward mainly during austral summer, while 
the northern edge shows no clear tendency. This would imply an SH STJ that shifts poleward as temperature increases, features that are not observed in Figs. 3, 4 (which actually show the opposite), or 5 (which shows no STJ migrations during the different periods).

The analysis of 21 st century climate projections presented by Lu et al. (2007, 2008) and Seo et al. (2014) suggests a weakening of the $\mathrm{HC}$ and its poleward expansion, associated with global warming. According to the range of 21 st century simulations analyzed by D'Agostino et al. (2017), the HC widens and weakens with global warming, with the changes in the tropical mean temperature being the best predictor of $\mathrm{HC}$ variations.

In summary, our analyses indicate that the climate models considered in this study do not adequately represent the ITCZ and HC changes reported in other studies. According to Schneider et al. (2014), biases in the model representation of important features such as clouds could distort the atmospheric energy flux and account for the difficulties representing ITCZ changes. In particular, Fig. 5 shows that the four models considered in this work exhibit a double peak of maximum precipitation between $8^{\circ} \mathrm{N}$ and $8^{\circ} \mathrm{S}$. This is observed at an annual scale when both peaks present the same amplitude $\left(\sim 6.7 \mathrm{~mm} \mathrm{~d}^{-1}\right)$ and in austral winter (JJA) when this behavior is more evident, with a main peak at $8^{\circ} \mathrm{N}$ reaching $\sim 8.5 \mathrm{~mm} \mathrm{~d}^{-1}$ and a secondary maximum of $\sim 3.8 \mathrm{~mm} \mathrm{~d}^{-1}$ at $6^{\circ} \mathrm{S}$. Individual models show generally similar results (Fig. S2).

Such bias is well known as the "double ITCZ bias". Although some studies suggest that this bias has been reduced from CMIP3 to CMIP5 models (Hirota and Takayabu, 2013), it is still a systematic bias in current climate models (Hwang and Frierson, 2013). Among the different possible causes linked to this bias are a cloud deficit over the Southern Hemisphere (Hwang and Frierson, 2013), insufficient cooling by ocean mesoscale eddies from the upwelling region (Colas et al., 2012), warm SST biases in the coastal upwelling of Peru (Gordon et al., 2000), and an underestimation of stratocumulus clouds over Peru (Ma et al., 1996).

\section{Concluding remarks}

Our results suggest important relative changes in major climatic features of the western margin of South America during the late Holocene. In particular, according to several paleoclimate proxies for southwestern SA and four CMIP5/PMIP3 models, we infer that important differences in the SPSH strength and position, alongshore wind intensity, and SWW position occurred between two of the most remarkable global climate events of the LM: the LIA and the CWP. In this sense, it should be noted that this work aims to establish a qualitative comparison between periods characterized by extreme climate conditions.
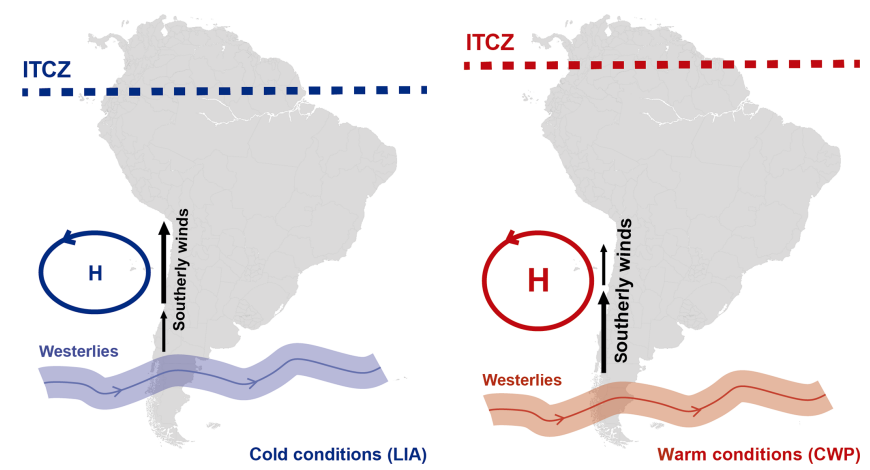

Figure 6. Schematics of the changes proposed in this work. The SPSH has changed from a contracted condition during the LIA period to an expanded state, with its southern rim reaching higher latitudes during the CWP. Coastal meridional winds appear to be stronger (weaker) south (north) of $\sim 35^{\circ}$ in the prevailing warm conditions. The opposite is observed during the cold period (LIA). The belt of SWWs shows a poleward position in the CWP, while it displays a northward shift during the LIA.

According to our results the SPSH has changed from a contracted condition during the LIA period to an expanded state, with its southern rim reaching higher latitudes during the CWP. Coinciding with these changes, coastal meridional winds appear to be stronger (weaker) south (north) of $\sim 35^{\circ}$ in the prevailing warm conditions (CWP). The opposite is observed during the cold period (LIA). The belt of SWWs shows a poleward position in the CWP, while it displays a northward shift during the LIA. These changes are in good agreement when comparing model results with proxy evidence from southwestern SA for the LIA and the present-day climate. This is also supported by paleoclimate reconstructions developed in other places of the $\mathrm{SH}$ and the tropical area of the NH. Figure 6 displays a scheme that integrates the paleoclimate evidence and model results for extratropical latitudes and summarizes these changes.

When evaluating historical experiments against ERAInterim reanalysis data, important differences can be observed. Reanalysis data present an SPSH more expanded, especially during austral summer, than that represented by climate models. Reanalyses also differ in representing the present-day behavior of the STJ, which is located some degrees north of those displayed by simulations and observations. In addition, reanalysis shows biases regarding the SWW core, which is located further south when this wind belt meets the continent all year.

The effects of global warming could continue impacting the South American climate. This is suggested by climate model projections, which indicate that the SPSH will continue to expand throughout the 21 st century. This expansion would also affect the intensity of the alongshore winds and the position and strength of the SWW belt. 
According to the literature, all these changes seem to be related mainly to changes in the ITCZ position and the Hadley circulation, but also to extratropical atmospheric dynamics. In fact, previous studies have shown that the ITCZ moved southward relative to its mean position during the LIA as a response to $\mathrm{NH}$ cooling and has been displaced northward (and/or expands its latitudinal range of movement) in the present-day warm conditions (Fig. 6). However, the models considered in this work fail to adequately represent these features, not being consistent with theory or the paleorecord evidence. In particular, model results show a weaker southern branch of the $\mathrm{HC}$ during the CWP in comparison to the LIA and show no significant changes in the Atlantic ITCZ during both periods. Biases in representing some features in models that distort the atmospheric energy flux could account for the difficulties exhibited by the considered climate models in correctly representing the ITCZ. The models analyzed here suggest that the Pacific ITCZ shifts southward as global temperature increases, and the STJ changes from a southward position during the LIA to a northward location during the CWP and continues moving to the north by the end of the 21 st century, contradicting the general trend of a poleward shift of the STJ under the current global warming conditions seen in climate models and recent observations. These unexpected results emphasize the importance of improving the ability to simulate Southern Hemisphere circulation to produce reliable climate projections and the need for complementary analyses to reduce uncertainties.

Finally, our findings provide important insights about the regional impacts of the ongoing climate change in the $\mathrm{SH}$ by integrating paleoclimate records of southwestern South America and global climate models. In view of the results from this work, we highlight the need to establish adequate mitigation and adaptation strategies to prevent the impacts of current and future climate change in southwestern South America.

Data availability. GCMs and Era-Interim reanalysis data used in this paper can be freely and openly accessed online at the following web addresses: https://esgf-node.llnl.gov/projects/cmip5/ (last access: 5 November 2019) (Taylor et al., 2012) and https://www. ecmwf.int/en/forecasts/datasets/reanalysis-datasets/era-interim (last access: 30 March 2019) (Dee et al., 2011), respectively.

Supplement. The supplement related to this article is available online at: https://doi.org/10.5194/cp-16-79-2020-supplement.

Author contributions. VFA and MR conceived the central idea of this paper. MR, CA, and PAA developed the model code and performed the simulations. VFA carried out the paleoclimate and paleoenvironmental record review. CG contributed with the reanalysis data. VFA prepared the paper, and all authors discussed the results and contributed to the final work.
Competing interests. The authors declare that they have no conflict of interest.

Acknowledgements. This work was partially funded by the Millennium Science Initiative of the Ministry of Economy, Development and Tourism under grant "Nuclei for Paleoclimate". Valentina Flores-Aqueveque was supported by FONDECYT grant no. 1191942 and grants from Santander Universidades (Beca Iberoamérica) and Alianza del Pacífico. Maisa Rojas was supported by FONDECYT no. 1171773. Catalina Aguirre acknowledges support by CONICYT through PAI program no. 79150062 and FONDECYT grant no. 11171163. Paola A. Arias was funded by grant PRG2017-16264 provided by Comité para el Desarrollo de la Investigación (CODI) at Universidad de Antioquia, Colombia. The authors also want to thank the editor and two anonymous reviewers for their suggestions and constructive comments, which helped us to improve the paper.

Financial support. This research has been supported by FONDECYT Regular (grant no. 1191942).

Review statement. This paper was edited by Laurie Menviel and reviewed by two anonymous referees.

\section{References}

Aceituno, P., Fuenzalida, H., and Rosenblüth, B.: Climate along the extratropical west coast of South America, in: Earth system responses to global change, edited by: Mooney, H. A., Fuentes, E. R., and Kronberg, B. I., Academic Press, 61-69, 1993.

Aguirre, C., García-Loyola, S., Testa, G., Silva, D., and Farías, L.: Insight into anthropogenic forcing on coastal upwelling off south-central Chile, Elem. Sci. Anth., 6, 59, https://doi.org/10.1525/elementa.314, 2018.

Allen, M. R., Dube, O. P., Solecki, W., Aragón-Durand, F., Cramer, W., Humphreys, S., Kainuma, M., Kala, J., Mahowald, N., Mulugetta, Y., Perez, R., Wairiu, M., and Zickfeld, K.: Framing and Context, in: Global Warming of $1.5^{\circ} \mathrm{C}$. An IPCC Special Report on the impacts of global warming of $1.5^{\circ} \mathrm{C}$ above pre-industrial levels and related global greenhouse gas emission pathways, in the context of strengthening the global response to the threat of climate change, sustainable development, and efforts to eradicate poverty [Masson-Delmotte, V., Zhai, P., Pörtner, H.-O., Roberts, D., Skea, J., Shukla, P.R., Pirani, A., Moufouma-Okia, W., Péan, C., Pidcock, R., Connors, S., Matthews, J.B.R., Chen, Y., Zhou, X., Gomis, M.I., Lonnoy, E., Maycock, T., Tignor, M. and Waterfield, T. (eds.)], World Meteorological Organization, Geneva, Switzerland, 32 pp., 2018.

Anabalón, V., Morales, C. E., Gonzalez, H. E., Menschel, E., Schneider, W., Hormazabal, S., Valencia, L., and Escribano, R.: Micro-phytoplankton community structure in the coastal upwelling zone off Concepción (central Chile): Annual and interannual fluctuations in a highly dynamic environment, Prog. Oceanogr., 149, 174-188, 2016. 
Ancapichún, S. and Garcés-Vargas, J.: Variability of the Southeast Pacific Subtropical Anticyclone and its impact on sea surface temperature off northcentral Chile, Ciencias Marinas, 41, 1-20, https://doi.org/10.7773/cm.v41i1.2338, 2015.

Barrett, B. S. and Hameed, S.: Seasonal Variability in Precipitation in Central and Southern Chile: Modulation by the South Pacific High, J. Climate, 30, 55-69, 2017.

Bentley, M. J., Hodgson, D. A., Smith, J. A., O Cofaigh, C., Domack, E. W., Larter, R. D., Roberts, S. J., Brachfeld, S., Leventer, A., Hjort, C., Hillenbrand, C.-D., and Evans, J.: Mechanisms of Holocene palaeoenvironmental change in the Antarctic Peninsula region, Holocene, 19, 51-69, 2009.

Belmadani, A., Echevin, V., Codron, F., Takahashi, K., and Junquas, C.: What dynamics drive future wind scenarios for coastal upwelling off Peru and Chile?, Clim. Dynam., 43, 1893-1914, https://doi.org/10.1007/s00382-013-2015-2, 2014.

Bertrand, S., Hughen, K., Sepúlveda, J., and Pantoja, S.: Late Holocene covariability of the southern westerlies and sea surface temperature in northern Chilean Patagonia, Quaternary Sci. Rev., 105, 195-208, 2014.

Boisier, J. P., Rondanelli, R., Garreaud, R., and Muñoz, F.: Anthropogenic and natural contributions to the Southeast Pacific precipitation decline and recent megadrought in central Chile, Geophys. Res. Lett., 43, 413-421, https://doi.org/10.1002/2015GL067265, 2016.

Boisier, J. P., Alvarez-Garretón, C., Cordero, R. R., Damiani, A., Gallardo, L., Garreaud, R. D., Lambert, F., Ramallo, C., Rojas, M., and Rondanelli, R.: Anthropogenic drying in central-southern Chile evidenced by long-term observations and climate model simulations, Elem. Sci. Anth., 6, 74, https://doi.org/10.1525/elementa.328, 2018.

Bracegirdle, T. J., Hyder, P., and Holmes, C. R.: CMIP5 diversity in southern westerly jet projections related to historical sea ice area: Strong link to strengthening and weak link to shift, J. Climate, 31, 195-211, 2018.

Bradley, R. S. and Jones, P. D.: 'Little Ice Age' Summer Temperature Variations: their Nature and Relevance to Recent Global Warming Trends, Holocene, 3, 367-376, 1993.

Briceño-Zuluaga, F. J., Sifeddine, A., Caquineau, S., Cardich, J., Salvatteci, R., Gutierrez, D., Ortlieb, L., Velazco, F., Boucher, H., and Machado, C.: Terrigenous material supply to the Peruvian central continental shelf (Pisco, $14^{\circ} \mathrm{S}$ ) during the last 1000 years: paleoclimatic implications, Clim. Past, 12, 787-798, https://doi.org/10.5194/cp-12-787-2016, 2016.

Briffa, K. R.: Annual climate variability in the Holocene: interpreting the message of ancient trees, Quaternary Sci. Rev., 19, 87105,2000

Briffa, K. R., Jones, P. D., Schweingruber, F. H., Shiyatov, S. G., and Cook, E. R.: Unusual 20th-century summer warmth in a 1000-year temperature record from Siberia, Nature, 376, 156159,1995

Browne, I. M., Moy, C. M., Riesselman, C. R., Neil, H. L., Curtin, L. G., Gorman, A. R., and Wilson, G. S.: Late Holocene intensification of the westerly winds at the subantarctic Auckland Islands $\left(51^{\circ} \mathrm{S}\right)$, New Zealand, Clim. Past, 13, 1301-1322, https://doi.org/10.5194/cp-13-1301-2017, 2017.

Cabré, M. F., Solman, S., and Núñez, M.: Regional climate change scenarios over southern South America for future climate (2080-2099) using the MM5 Model, Mean, inter- annual variability and uncertainties, Atmósfera, 29, 35-60, https://doi.org/10.20937/ATM.2016.29.01.04, 2016.

Cane, M. A.: Climate change - a role for the tropical Pacific, Science, 282, 60-61, 1998.

Cane, M. A.: The evolution of El Niño, past and future, Earth Planet. Sc. Lett., 230, 227-240, 2005.

Chambers, F. M., Brain, S. A., Mauquoy, D., McCarroll, J., and Daley, T.: The 'Little Ice Age' in the Southern Hemisphere in the context of the last 3000 years: Peat-based proxy-climate data from Tierra del Fuego, The Holocene, 24, 1649-1656, 2014.

Chavaillaz, Y., Codron, F., and Kageyama, M.: Southern westerlies in LGM and future (RCP4.5) climates, Clim. Past, 9, 517-524, https://doi.org/10.5194/cp-9-517-2013, 2013.

Colas F., McWilliams, J. C., Capet, X., and Kurian, J.: Heat balance and eddies in the Peru-Chile current system, Clim. Dynam., 39, 509-529, 2012.

Croquette, M., Eldin, G., Grados, C., and Tamayo, M.: On differences in satellite wind products and their effects in estimating coastal upwelling processes in the south-east Pacific, Geophys. Res. Lett., 34, https://doi.org/10.1029/2006GL027538, 2007.

Crowley, T. J. and Lowery, T. S.: How warm was the medieval warm period?, Ambio, 29, 51-54, 2000.

D'Agostino, R. and Lionello, P.: Evidence of global warming impact on the evolution of the Hadley Circulation in ECMWF centennial reanalyses, Clim. Dynam., 48, 3047-3060, 2016.

D’Agostino, R., Lionello, P., Adam, O., and Schneider, T.: Factors controlling Hadley circulation changes from the Last Glacial Maximum to the end of the 21 st century, Geophys. Res. Lett., 44, 8585-8591, https://doi.org/10.1002/2017GL074533, 2017.

Dee, D. P., Uppala, S. M., Simmons, A. J., Berrisford, P., Poli, P., Kobayashi, S., Andrae, U., Balmaseda, M. A., Balsamo, G., Bauer, P., Bechtold, P., Beljaars, A. C. M., van de Berg, L., Bidlot, J., Bormann, N., Delsol, C., Dragani, R., Fuentes, M., Geer, A. J., Haimberger, L., Healy, S. B., Hersbach, H., Holm, E. V., Isaksen, L., Kållberg, P., Köhler, M., Matricardi, M., McNally, A. P., Monge-Sanz, B. M., Morcrette, J.-J., Park, B.-K., Peubey, C., de Rosnay, P., Tavolato, C., Thepaut, J.-N., and Vitart, F.: The ERA-Interim reanalysis: configuration and performance of the data assimilation system, Q. J. Roy. Meteorol. Soc., 137, 553597, https://doi.org/10.1002/qj.828, 2011.

Deng, W., Liu, X., Chen, X., Wei, G., Zeng, T., Xie, L., and Zhao, J.-X.: A comparison of the climates of the Medieval Climate Anomaly, Little Ice Age, and Current Warm Period reconstructed using coral records from the northern South China Sea, J. Geophys. Res.-Oceans, 122, 264-275, https://doi.org/10.1002/2016JC012458, 2017.

Denniston, R. F., Ummenhofer, C. C., Wanamaker Jr., A. D., Lachniet, M. S., Villarini, G., Asmerom, Y., Polyak, V. J., Passaro, K. J., Cugley, J., Woods, D., and Humphreys, W. F.: Expansion and Contraction of the Indo-Pacific Tropical Rain Belt over the Last Three Millennia, Sci. Rep., 6, 34485, https://doi.org/10.1038/srep34485, 2016.

Dettinger, M. D., Battisti, D. S., Garreaud, R. D., McCabe, G. J., and Bitz, C. M.: Interhemispheric effects of interannual and decadal ENSO-like climate variations on the Americas, in: Interhemispheric climate linkages: Present and Past Climates in the Americas and their Societal Effects, edited by: Markgraf, V., Academic Press, San Diego, 1-16, 2000. 
Díaz, L. B. and Vera, C.: South American precipitation changes simulated by PMIP3/CMIP5 models during the Little Ice Age and the recent global warming period, Int. J. Climatol., 38, 26382650, 2018.

Dufresne, J.-L., Foujols, M.-A., Denvil, S., Caubel, A., Marti, O., Aumont, O., Balkanski, Y., Bekki, S., Bellenger, H., Benshila, R., Bony, S., Bopp, L., Braconnot, P., Brockmann, P., Cadule, P., Cheruy, F., Codron, F., Cozic, A., Cugnet, D., deNoblet, N., Duvel, J. P., Ethé, C., Fairhead, L., Fichefet, T., Flavoni, S., Friedlingstein, P., Grandpeix, J.-Y., Guez, L., Guilyardi, E., Hauglustaine, D., Hourdin, F., Idelkadi, A., Ghattas, J., Joussaume, S., Kageyama, M., Krinner, G., Labetoulle, S., Lahellec, A., Lefebvre, M.-P., Lefevre, F., Levy, C., Li, Z. X., Lloyd, J., Lott, F., Madec, G., Mancip, M., Marchand, M., Masson, S., Meurdesoif, Y., Mignot, J., Musat, I., Parouty, S., Polcher, J., Rio, C., Schulz, M., Swingedouw, D., Szopa, S., Talandier, C., Terray, P., and Viovy, N.: Climate change projections using the IPSLCM5 Earth System Model: from CMIP3 to CMIP5, Clim. Dynam., 40, 2123-2165, https://doi.org/10.1007/s00382-012-16361, 2013.

Falvey, M. and Garreaud, R.: Regional cooling in a warming world: Recent temperature trends in the SE Pacific and along the west coast of subtropical South America (1979-2006), J. Geophys. Res., 114, D04102, https://doi.org/10.1029/2008JD010519, 2009.

Fleury, S., Martinez, P., Crosta, X., Charlier, K., Billy, I., Hanquiez, V., Blanz, T., and Schneider, R. R.: Pervasive multidecadal variations in productivity within the Peruvian Upwelling System over the last millennium, Quaternary Sci. Rev., 125, 78-90, https://doi.org/10.1016/j.quascirev.2015.08.006, 2015.

Flores-Aqueveque, V., Alfaro, S., Vargas, G., Rutllant, J. A., and Caquineau, S.: Aeolian particles in marine cores as a tool for quantitative high-resolution reconstruction of upwelling favorable winds along coastal Atacama Desert, Northern Chile, Prog. Oceanogr., 134, 244-255, 2015.

Folland, C. K., Rayner, N. A., Brown, S. J., Smith, T. M., Shen, S. S., Parker, D. E., Macadam, I., Jones, P. D., Jones, R. N., Nicholls, N., and Sexton, D. M. H.: Global temperature change and it uncertainties since 1861, Geophys. Res. Lett., 28, 26212624, 2001.

Fuenzalida, H.: Climatología de Chile, Publicación interna, Departamento de Geofísica, Univ. de Chile, 73 pp., 1971.

Fyfe, J. C. and Saenko, O. A.: Simulated changes in the extratropical Southern Hemisphere winds and currents, Geophys. Res. Lett., 33, L06701, https://doi.org/10.1029/2005GL025332, 2006.

Garreaud, R. D. and Battisti, D. S.: Interannual (ENSO) and interdecadal (ENSO-like) variability in the Southern Hemisphere tropospheric circulation, J. Climate, 2, 2113-2123, 1999.

Garreaud, R. and Falvey, M.: The coastal winds off western subtropical South America in future climate scenarios, Int. J. Climatol., 29, 543-554, 2009.

Garreaud, R. N., Vuille, M., Compagnucci, R., and Matengo, J.: Present-day South American climate, Palaeogeogr. Palaeocl., 281, 180-195, 2009.

Garreaud, R., Lopez, P., Minvielle, M., and Rojas, M.: Large-scale control on the Patagonian climate, J. Climate, 26, 215-230, 2013.

Gent, P. R., Danabasoglu, G., Donner, L. J., Holland, M. M., Hunke, E. C., Jayne, S. R., Lawrence, D. M., Neale, R. B., Rasch, P. J., Vertenstein, M., Worley, P. H., Yang, Z. L., and Zhang, M.:
The community climate system model version 4, J. Climate, 24, 4973-4991, https://doi.org/10.1175/2011JCLI4083.1, 2011.

Gillet, N. and Thompson, D.: Simulation of Recent Southern Hemisphere Climate Change, Science, 302, 273-275, https://doi.org/10.1126/science.1087440, 2003.

Gillett, N. P. and Fyfe, J. C.: Annular mode changes in the CMIP5 simulations, Geophys. Res. Lett., 40, 1189-1193, https://doi.org/10.1002/grl.50249, 2013.

Gillett, N. P. and Parker, D. E.: Attribution of observed sea level pressure trends to greenhouse gas, aerosol, and ozone changes, Geophys. Res. Lett., 40, 2302-2306, https://doi.org/10.1002/grl.50500, 2013.

González-Reyes, Á.: Modelación de la Línea de Equilibrio Glaciar durante los últimos 500 años y variaciones climáticas recientes en los Andes Mediterráneos de Chile ( $\left.30^{\circ}-37^{\circ} \mathrm{S}\right)$, Ph.D. thesis, Universidad de Chile, Chile, 121 pp., 2019.

Gordon C. T., Rosati, A., and Gudgel, R.: Tropical sensitivity of a coupled model to specified ISCCP low clouds, J. Climate, 13, 2239-2260, 2000.

Grotjahn, R.: Remote weather associated with South Pacific Subtropical sea-level High properties, Int. J. Climatol., 24, 823-839, 2004.

Gutiérrez, D., Sifeddine, A., Field, D. B., Ortlieb, L., Vargas, G., Chávez, F. P., Velazco, F., Ferreira, V., Tapia, P., Salvatteci, R., Boucher, H., Morales, M. C., Valdés, J., Reyss, J.-L., Campusano, A., Boussafir, M., Mandeng-Yogo, M., García, M., and Baumgartner, T.: Rapid reorganization in ocean biogeochemistry off Peru towards the end of the Little Ice Age, Biogeosciences, 6, 835-848, https://doi.org/10.5194/bg-6-835-2009, 2009.

Hansen, J., Ruedy, R., Sato, M., and Lo, K.: Global surface temperature change, Rev. Geophys., 48, RG4004, https://doi.org/10.1029/2010RG000345, 2010.

Hartmann, D. L., Klein Tank, A. M. G., Rusticucci, M., Alexander, L. V., Brönnimann, S., Charabi, Y., Dentener, F. J., Dlugokencky, E. J., Easterling, D. R., Kaplan, A., Soden, B. J., Thorne, P. W., Wild, M., and Zhai, P. M.: Observations: Atmosphere and Surface, in: Climate Change 2013: The Physical Science Basis. Contribution of Working Group I to the Fifth Assessment Report of the Intergovernmental Panel on Climate Change, Cambridge University Press, Cambridge, United Kingdom and New York, NY, USA, 2013.

Haug, G. H., Hughen, K. A., Sigman, D. M., Peterson, L. C., and Rohl, U.: Southward Migration of the Intertropical Convergence Zone through the Holocene, Science, 293, 1304-1307, https://doi.org/10.1126/science.1059725, 2001.

Held, I. M. and Hou, A. Y.: Nonlinear axially symmetric circulations in a nearly inviscid atmosphere, J. Atmos. Sci., 37, 515533, 1980.

Hirota, N. and Takayabu, Y. N.: Reproducibility of precipitation distribution over the tropical oceans in CMIP5 multi-climate models compared to CMIP3, Clim. Dynam., 41, 2909-2920, https://doi.org/10.1007/s00382-013-1839-0, 2013.

Hourdin, F., Musat, I., Bony, S., Braconnot, P., Codron, F., Dufresne, J.-L., Fairhead, L., Filiberti, M.-A., Friedlingstein, P., Grandpeix, J.-I., Krinner, G., LeVan, P., Li, Z. X., and Lott, F.: The LMDZ4 general circulation model: climate performance and sensitivity to parametrized physics with emphasis on tropical convection, Clim. Dynam., 27, 787-813, https://doi.org/10.1007/s00382-006-0158-0, 2006. 
Hudson, R. D.: Measurements of the movement of the jet streams at mid-latitudes, in the Northern and Southern Hemispheres, 1979 to 2010, Atmos. Chem. Phys., 12, 7797-7808, https://doi.org/10.5194/acp-12-7797-2012, 2012.

Hwang, Y. T. and Frierson, D. M.: Link between the doubleIntertropical Convergence Zone problem and cloud biases over the Southern Ocean, P. Natl. Acad. Sci. USA, 110, 4935-4940, 2013.

Ihara, C. and Kushnir, Y.: Change of mean midlatitude westerlies in 21 st century climate simulations, Geophys. Res. Lett., 36, L13701, doi:10.1029/2009GL037674, 2009.

Ihara, C. and Kushnir, Y.: Change of mean midlatitude westerlies in 21 st century climate simulations, Geophys. Res. Lett., 36, L13701, https://doi.org/10.1029/2009GL037674, 2013.

Jenny, B., Valero-Garcés, B. L., Urrutia, R., Kelts, K., Veit, H., Appleby, P. G., and Geyh, M.: Moisture changes and fluctuations of the Westerlies in Mediterranean Central Chile during the last 2000 years: the Laguna Aculeo record $\left(33^{\circ} 50^{\prime} \mathrm{S}\right)$, Quaternary Int., 87, 3-18, 2002.

Johnson, T. C., Barry, S. L., Chan, Y., and Wilkinson, P.: Decadal record of climate variability spanning the past $700 \mathrm{yr}$ in the Southern Tropics of East Africa, Geology, 29, 83-86, 2001.

Jones, P. D. and Mann, M. E.: Climate Over Past Millennia, Rev. Geophys., 42, RG2002, https://doi.org/10.1029/2003RG000143, 2004.

Jones, P. D., Briffa, K. R., Barnett, T. P., and Tett, S. F. B.: Highresolution palaeoclimatic records for the last millennium: interpretation, integration and comparison with General Circulation Model control run temperatures, The Holocene, 8, 467-473, 1998.

Jones, P. D., Osborn, T. J., and Briffa, K. R.: The evolution of climate over the last millennium, Science, 292, 662-667, 2001.

Kitoh, A., Kusunoki, S., and Nakaegawa, T.: Climate change projections over South America in the late 21st century with the 20 and $60 \mathrm{~km}$ mesh Meteorological Research Institute atmospheric general circulation model (MRI-AGCM), J. Geophys. Res., 116, D06105, https://doi.org/10.1029/2010JD014920, 2011.

Koch, J.: Little Ice Age and recent glacier advances in the Cordillera Darwin, Tierra del Fuego, Chile, Anales Instituto Patagonia (Chile), 43, 127-136, 2015.

Koch, J. and Kilian, R.: 'Little Ice Age' glacier fluctuations, Gran Campo Nevado, southernmost Chile, The Holocene, 15, 20-28, 2005.

Koffman, B. G., Kreutz, K. J., Breton, D. J., Kane, E. J., Winski, D. A., Birkel, S. D., Kurbatov, A. V., and Handley, M. J.: Centennial-scale variability of the Southern Hemisphere westerly wind belt in the eastern Pacific over the past two millennia, Clim. Past, 10, 1125-1144, https://doi.org/10.5194/cp-10-11252014, 2014.

Lamy, F., Hebbeln, D., Röhl, U., and Wefer, G.: Holocene rainfall variability in southern Chile: a marine record of latitudinal shifts of the Southern Westerlies, Earth Planet. Sc. Lett., 185, 369-382, 2001.

Lee, S.-Y., Chiang, J. C. H., Matsumoto, K., and Tokos, K. S.: Southern Ocean wind response to North Atlantic cooling and the rise in atmospheric $\mathrm{CO}_{2}$ : Modeling perspective and paleoceanographic implications, Paleoceanography, 26, PA1214, https://doi.org/10.1029/2010PA002004, 2011.
Levitus, S., Antonov, J. I., Boyer, T. P., and Stephens, C.: Warming of the world ocean, Science, 287, 2225-2229, 2000.

Lu, J., Vecchi, G. A., and Reichler, T.: Expansion of the Hadley cell under global warming, Geophys. Res. Lett., 34, L06805, https://doi.org/10.1029/2006GL028443, 2007.

Lu, J., Chen, G., and Frierson, D. M.: Response of the zonal mean atmospheric circulation to El Niño versus global warming, J. Climate, 21, 5835-5851, 2008.

Ma, C. C., Mechoso, C. R., Robertson, A. W., and Arakawa, A.: Peruvian stratus clouds and the tropical Pacific circulation: A coupled ocean-atmosphere GCM study, J. Climate, 9, 1635-1645, 1996.

Mann, M. E.: Little Ice Age, in: Encyclopedia of Global Environmental Change, edited by: MacCracken, M. C. and Perry, J. S., 504-509, John Wiley, Chichester, UK, 2002.

Mann, M. E., Bradley, R. S., and Hughes, M. K.: Northern Hemisphere Temperatures during the Past Millennium: Inferences, Uncertainties, and Limitations, Geophys. Res. Lett., 26, 759762, 1999.

Mann, M. E., Ammann, C. M., Bradley, R. S., Briffa, K. R., Crowley, T. J., Hughes, M. K., Jones, P. D., Oppenheimer, M., Osborn, T. J., Overpeck, J. T., Rutherford, S., Trenberth, K. E., and Wigley, T. M. L.: On Past Temperatures and Anomalous Late 20th Century Warmth, Eos, 84, 256-258, 2003.

Mantua, N. J., Hare, S. R., Zhang, Y., Wallace, J. M., and Francis, R. C.: A Pacific interdecadal climate oscillation with impacts on salmon production, B. Am. Meteorol. Soc., 78, 1069-1079, 1997.

Mantua, N. J. and Hare, S. R.: The Pacific Decadal Oscillation, J. Oceanogr., 58, 35-44, https://doi.org/10.1023/A:1015820616384, 2002.

Marcott, S. A., Shakun, J. D., Clark, P. U., and Mix, A. C.: A reconstruction of regional and global temperature for the past 11,300 years, Science, 339, 6124, 1198-1201, https://doi.org/10.1126/science.1228026, 2013.

Marshall, G. J., Stott, P. A., Turner, J., Connolley, W. M., King, J. C., and Lachlan-Cope, T. A.: Causes of exceptional atmospheric circulation changes in the Southern Hemisphere, Geophys. Res. Lett., 31, L14205, https://doi.org/10.1029/2004GL019952, 2004

Masiokas, M., Rivera, A., Espizua, L. E., Villalba, R., Delgado, S., and Aravena, J. C.: Glacier fluctuations in extratropical South America during the past 1000 years, Palaeogeogr. Palaeocl., 281, 242-268, 2009.

Meehl, G., Tebaldi, C., Teng, H., and Peterson, T.: Current and future U.S. weather extremes and El Niño, Geophys. Res. Lett., 34, L20704, https://doi.org/10.1029/2007GL031027, 2007.

Menviel, L., Spence, P., Yu, J., Chamberlain, M. A., Matear, R. J., Meissner, K. J., and England, M. H.: Southern Hemisphere westerlies as a driver of the early deglacial atmospheric $\mathrm{CO}_{2}$ rise, Nat. Commun., 9, 2503, https://doi.org/10.1175/JCLI-D-13-00701.1, 2018.

Moreno, P. I., François, J. P., Villa-Martínez, R., and Moy, C. M.: Millennial-scale variability in Southern Hemisphere westerly wind activity over the last 5000 years in SW Patagonia, Quaternary Sci. Rev., 28, 25-38, 2009.

Moreno, P. I., Vilanova, I., Villa-Martínez, R., Garreaud, R. D., Rojas, M., and De Pol-Holz, R.: Southern Annular Mode-like changes in southwestern Patagonia at centennial 
timescales over the last three millennia, Nat. Commun., 5, 4375, https://doi.org/10.1038/ncomms5375, 2014.

Moy, C. M., Dunbar, R. B., Moreno, P. I., François, J. P., VillaMartínez, R., Mucciarone, D. M., Guilderson, T. O., and Garreaud, R.: Isotopic evidence for hydrologic change related to the westerlies in SW Patagonia, Chile, during the last millennium, Quaternary Sci. Rev., 27, 1335-1349, 2008.

Moy, C. M., Moreno, P., Dunbar, R., Kaplan, M., François, J. P., Villalba, R., and Haberzettl, T.: Climate Change in Southern South America During the Last Two Millennia, Past Climate Variability in South America and Surrounding Regions, Develop. Paleoenviron. Res., 14, 353-393, 2009.

Neukom, R., Gergis, J., Karoly, D., Wanner, H., Curran, M., Elbert, J., González-Rouco, F., Linsley, B., Moy, A. D., Mundo, I. A., Raible, C. C., Steig, E. J., Van Ommen, T., Vance, T., Villalba, R., Zinke, J., and Frank, D.: Inter-hemispheric temperature variability over the past millennium, Nat. Clim. Change, 4, 362-367, https://doi.org/10.1038/NCLIMATE2174, 2014.

Nuñez, M. N., Solman, S. A., and Cabré, M. F.: Regional climate change experiments over southern South America. II: Climate change scenarios in the late twenty-first century, Clim. Dynam., 32, 1081-1095, 2008.

Ortega, C., Vargas, G., Rojas, M., Rutllant, J. A., Muñoz, P., Lange, C. B., Pantoja, S., Dezileau, L., and Ortlieb, L.: Extreme ENSO-driven torrential rainfalls at the southern edge of the Atacama Desert during the Late Holocene and their projection into the 21th century, Global Planet. Change, 175, 226-237, https://doi.org/10.1016/j.gloplacha.2019.02.011, 2019.

Osborn, T. J. and Briffa, K. R.: The spatial extent of 20th-century warmth in the context of the past 1200 years, Science, 311, 841844, 2006.

PAGES2k Consortium: Continental-scale temperature variability during the past two millennia, Nat. Geosci., 6, 339-346, https://doi.org/10.1038/NGEO1797, 2013.

PAGES2k Consortium: A global multiproxy database for temperature reconstructions of the Common Era, Sci. Data, 4, 170088, https://doi.org/10.1038/sdata.2017.88, 2017.

PAGES2k Consortium: Consistent multidecadal variability in global temperature reconstructions and simulations over the Common Era, Nat. Geosci., 12, 643-649, 2019.

Peterson, L. C. and Haug, G. H.: Variability in the mean latitude of the Atlantic Intertropical Convergence Zone as recorded by riverine input of sediments to the Cariaco Basin (Venezuela), Palaeogeogr. Palaeocl., 234, 97-113, 2006.

Pittock, A. B.: Patterns of Climatic Variation in Argentina and Chile - I. Precipitation, 1931-60, Meteorológica, 11, 73-97, 1980.

Pizarro, O., Hormazábal, S., González, A., and Yáñez, E.: Variabilidad del viento, nivel del mar y temperatura en la costa norte de Chile, Investigaciones Marinas, Valparaíso, 22, 83-101, 1994.

Quintana, J. M. and Aceituno, P.: Changes in the rainfall regime along the extratropical west coast of South America (Chile): 30 $43^{\circ} \mathrm{S}$, Atmosfera, 25, 1-22, 2012.

Rahn, D. A. and Garreaud, R. D.: A synoptic climatology of the near-surface wind along the west coast of South America, Int. J. Climatol., 34, 780-792, https://doi.org/10.1002/joc.3724, 2013.

Rasmussen, E. M. and Wallace, J. M.: Meteorological aspects of the El Niño/Southern Oscillation, Science, 222, 1195-1202, 1983.

Rodwell, M. J. and Hoskins, B. J.: Subtropical anticyclones and summer monsoons, J. Cli- mate, 14, 3192-3211, https://doi.org/10.1175/15200442(2001)014<3192:SAASM>2.0.CO;2, 2001.

Rojas, M., Arias, P. A., Flores-Aqueveque, V., Seth, A., and Vuille, M.: The South American monsoon variability over the last millennium in climate models, Clim. Past, 12, 1681-1691, https://doi.org/10.5194/cp-12-1681-2016, 2016.

Rutllant, J., Fuenzalida, H., and Aceituno, P.: Climate dynamics along the arid northern coast of Chile: the 19971998 Dinámica del Clima de la Región de Antofagasta (DICLIMA) experiment, J. Geophys. Res.-Atmos., 108, 4358, https://doi.org/10.1029/2002JD003357, 2003.

Rykaczewski, R. R., Dunne, J. P., Sydeman, W. J., García-Reyes, M., Black, B. A., and Bograd, S. J.: Poleward displacement of coastal upwelling-favorable winds in the ocean's eastern boundary currents through the 21 st century, Geophys. Res. Lett., 42, 6424-6431, https://doi.org/10.1002/2015GL064694, 2015.

Sachs, J. P., Sachse, D., Smittenberg, R. H., Zhang, Z., Battisti, D. S., and Golubic, S.: Southward movement of the Pacific intertropical convergence zone AD 1400-1850, Nat. Geosci., 2, 519-525, 2009.

Salinas, C. X. and Mendieta, J.: Mitigation and adaptation investments for desertification and climate change: an assessment of the socioeconomic return, Mitig. Adapt Strateg. Glob. Change, 18, 659-672, 2013.

Salvatteci, R., Gutiérrez, D., Field, D., Sifeddine, A., Ortlieb, L., Bouloubassi, I., Boussafir, M., Boucher, H., and Cetin, F.: The response of the Peruvian Upwelling Ecosystem to centennial-scale global change during the last two millennia, Clim. Past, 10, 715731, https://doi.org/10.5194/cp-10-715-2014, 2014.

Saunders, K., Roberts, S., Perren, B., Butz, C., Sime, L., Davies, S., Van Nieuwenhuyze, W., Grosjean, M., and Hodgson, D.: Holocene dynamics of the Southern Hemisphere westerly winds and possible links to $\mathrm{CO}_{2}$ outgassing, Nat. Geosci., 2018.

Schimpf, D., Kilian, R., Kronz, A., Simon, K., Spotl, C., Worner, G., Deininger, M., and Mangini, A.: The significance of chemical, isotopic, and detrital components in three coeval stalagmites from the superhumid southernmost Andes $\left(53^{\circ} \mathrm{S}\right)$ as highresolution palaeo-climate proxies, Quaternary Sci. Rev., 30, 443459, 2011.

Schmidt, G. A., Jungclaus, J. H., Ammann, C. M., Bard, E., Braconnot, P., Crowley, T. J., Delaygue, G., Joos, F., Krivova, N. A., Muscheler, R., Otto-Bliesner, B. L., Pongratz, J., Shindell, D. T., Solanki, S. K., Steinhilber, F., and Vieira, L. E. A.: Climate forcing reconstructions for use in PMIP simulations of the last millennium (v1.0), Geosci. Model Dev., 4, 33-45, https://doi.org/10.5194/gmd-4-33-2011, 2011.

Schmidt, G. A., Jungclaus, J. H., Ammann, C. M., Bard, E., Braconnot, P., Crowley, T. J., Delaygue, G., Joos, F., Krivova, N. A., Muscheler, R., Otto-Bliesner, B. L., Pongratz, J., Shindell, D. T., Solanki, S. K., Steinhilber, F., and Vieira, L. E. A.: Climate forcing reconstructions for use in PMIP simulations of the Last Millennium (v1.1), Geosci. Model Dev., 5, 185-191, https://doi.org/10.5194/gmd-5-185-2012, 2012.

Schneider, T., Bischoff, T., and Haug, G. H.: Migrations and dynamics of the intertropical convergence zone, Nature, 513, 4553, 2014.

Schneider, W., Donoso, D., Garcés-Vargas, J., and Escribano, R.: Water-column cooling and sea surface salinity increase in the upwelling region off central-south Chile driven by a poleward 
displacement of the South Pacific High, Prog. Oceanogr., 151, 38-48, 2017.

Seo, K.-H., Frierson, D. M., and Son, J.-H.: A mechanism for future changes in Hadley circulation strength in cmip5 climate change simulations, Geophys. Res. Lett., 41, 5251-5258, 2014.

Sepúlveda, J., Pantoja, S., Hughen, K., Bertrand, S., Figueroa, D., Leon, T., Drenzek, N., and Lange, C.: Late Holocene sea-surface temperature and precipitation variability in northern Patagonia, Chile (Jacaf Fjord, $44^{\circ} \mathrm{S}$ ), Quaternary Res., 72, 400-409, https://doi.org/10.1016/j.yqres.2009.06.010, 2009.

Shindell, D. T. and Schmidt, G. A.: Southern Hemisphere Climate Response to Ozone Changes and Greenhouse Gas Increases, Geophys. Res. Lett., 31, L18209, https://doi.org/10.1029/2004g1020724, 2004.

Siffedine, A., Gutiérrez, D., Ortlieb, L., Boucher, H., Velazco, F., Field, D., Vargas, G., Boussafire, M., Salvatteci, R., Ferreira, V., García, M., Valdés, J., Caquineau, S., Mandeng Yogo, M., Cetin, F., Solis, J., Soler, P., and Baumgartner, T.: Laminated sediments from the central Peruvian continental slope: A 500 year record of upwelling system productivity, terrestrial runoff and redox conditions, Prog. Oceanogr., 79, 190-197, 2008.

Sime, L. C., Kohfeld, K. E., Le Quéré, C., Wolff, E. W., de Boer, A. M., Graham, R. M., and Bopp, L.: Southern Hemisphere westerly wind changes during the Last Glacial Maximum: model-data comparison, Quaternary Sci. Rev., 64, 104-120, 2013.

Son, S.-W., Gerber, E. P., Perlwitz, J., Polvani, L. M., Gillett, N. P., Seo, K.-H., Eyring, V., Shepherd, T. G., Waugh, D., Akiyoshi, H., Austin, J., Baumgaertner, A., Bekki, S., Braesicke, P., Brühl, C., Butchart, N., Chipperfield, M. P., Cugnet, D., Dameris, M., Dhomse, S., Frith, S., Garny, H., Garcia, R., Hardiman, S. C., Jöckel, P., Lamarque, J. F., Mancini, E., Marchand, M., Michou, M., Nakamura, T., Morgenstern, O., Pitari, G., Plummer, D. A., Pyle, J., Rozanov, E., Scinocca, J. F., Shibata, K., Smale, D., Teyssèdre, H., Tian, W., and Yamashita, Y.: Impact of stratospheric ozone on Southern Hemisphere circulation change: A multimodel assessment, J. Geophys. Res., 115, D00M07, https://doi.org/10.1029/2010JD014271, 2010.

Swart, N. C. and Fyfe, J. C.: Observed and simulated changes in the Southern Hemisphere surface westerly wind-stress, Geophys. Res. Lett., 39, L16711, https://doi.org/10.1029/2012GL052810, 2012.

Swart, N. C., Fyfe, J. C., Gillett, N., and Marshall, G. J.: Comparing trends in the Southern Annular Mode and surface westerly jet, J. Climate, 28, 8840-8859, https://doi.org/10.1175/JCLI-D-150334.1, 2015.

Taylor, K. E., Stouffer, R. J., and Meehl, G. A.: An overview of CMIP5 and the experiment design, B. Am. Meteorol. Soc., 93, 485-498, https://doi.org/10.1175/BAMS-D-11-00094.1, 2012.

Thompson, D. W. J. and Wallace, J. M.: Annular modes in the extratropical circulation, Part I: Month-to-month variability, J. Climate, 13, 1000-1016, 2000.

Thompson, D. W. J. and Solomon, S.: Interpretation of recent Southern Hemisphere climate change, Science, 296, 895-899, 2002.
Thompson, D. W. J., Wallace, J. M., and Hegerl, G. C.: Annular modes in the extratropical circulation, Part II: Trends, J. Climate, 13, 1018-1036, 2000.

Toggweiler, J. R.: Climate change: shifting westerlies, Science, 323, 1434, https://doi.org/10.1126/science.1169823, 2009.

van Hengstum, P. J., Donnelly, J. P., Fall, P. L., Toomey, M. R., Albury, N. A., and Kakuk, B.: The intertropical convergence zone modulates intense hurricane strikes on the western North Atlantic margin, Sci. Rep., 6, 21728, https://doi.org/10.1038/srep21728, 2016.

Varma, V., Prange, M., Merkel, U., Kleinen, T., Lohmann, G., Pfeiffer, M., Renssen, H., Wagner, A., Wagner, S., and Schulz, M.: Holocene evolution of the Southern Hemisphere westerly winds in transient simulations with global climate models, Clim. Past, 8, 391-402, https://doi.org/10.5194/cp-8-391-2012, 2012.

Vera, C., Silvestri, G., Liebmann, B., and González, P.: Climate change scenarios for seasonal precipitation in South America from IPCC-AR4 models, Geophys. Res. Lett., 33, L13707, https://doi.org/10.1029/2006GL025759, 2006.

Wang, D., Gouhier, T. C., Menge, B. A., and Ganguly, A. R.: Intensification and spatial homogenization of coastal upwelling under climate change, Nature, 318, 390-394, https://doi.org/10.1038/nature14235, 2015.

Williams, L. D. and Wigley, T. M. L.: A comparison of evidence for late Holocene summer temperature variations in the Northern Hemisphere, Quaternary Res., 20, 286-307, 1983.

Woollings, T. and Blackburn, M.: The North Atlantic jet stream under climate change and its relation to the NAO and EA patterns, J. Climate, 25, 886-902, 2012.

Wu, T., Song, L., Li, W., Wang, Z., Zhang., H., Xin, X., Zhang, Y., Zhang, L., Li, J., Wu., F., Liu, Y., Zhang, F., Shi, X., Chu, M., Zhang, J, Fang, Y., Wang, F., Lu, Y., Liu, X., Wei, M., Liu, Q., Zhou, W., Dong, M., Zhao, Q., Laurent, L., and Zhou, M.: An overview of BCC climate system model development and application for climate change studies, J. Meteor. Res., 28, 034-056, doi:10.1007/s13351-014-3041-7, 2014.

Xin, X.-G., Wu, T.-W., and Zhang, J.: Introduction of CMIP5 experiments carried out with the climate system models of Beijing Climate Center, Adv. Clim. Change Res., 4, doi:10.3724/SP.J.1248.2013.041, 2013.

Yan, H., Wei, W., Soon, W., An, Z., Zhou, W., Liu, Z., Wang, Y., and Carter, R. M.: Dynamics of the intertropical convergence zone over the western Pacific during the Little Ice Age, Nat. Geosci., 8, 315-320, 2015

Yukimoto, S., Yoshimura, H., Hosaka, M., Sakami, T., Tsujino, H., Hirabara, M., Tanaka, T. Y., Deushi, M., Obata, A., Nakano, H., Adachi, Y., Shindo, E., Yabu, S., Ose, T., and Kitoh, A.: Technical Report of the Meteorological Research Institute, 64, 83 pp., 2011.

Zhang, Y., Wallace, J. M., and Battisti, D. S.: ENSO-like interdecadal variability: 1900-1993, J. Climate, 10, 1004-1020, 1997. 